\title{
Neuroblastoma therapy: what is in the pipeline?
}

\author{
Carla S Verissimo ${ }^{1}$, Jan J Molenaar ${ }^{2}$, Carlos P Fitzsimons ${ }^{1,3}$ and \\ Erno Vreugdenhil ${ }^{1}$
}

\author{
${ }^{1}$ Division of Medical Pharmacology, Leiden/Amsterdam Center for Drug Research, Leiden University Medical Center, Gorlaeus \\ Laboratories, PO Box 9502, 2300 RA Leiden, The Netherlands \\ ${ }^{2}$ Department of Human Genetics, Academic Medical Center, Amsterdam, The Netherlands \\ ${ }^{3}$ Center for Neuroscience, Swammerdam Institute for Life Sciences, University of Amsterdam, Amsterdam, The Netherlands \\ (Correspondence should be addressed to E Vreugdenhil; Email: vreugden@lacdr.leidenuniv.nl)
}

\begin{abstract}
Despite the expansion of knowledge about neuroblastoma (NB) in recent years, the therapeutic outcome for children with a high-risk NB has not significantly improved. Therefore, more effective therapies are needed. This might be achieved by aiming future efforts at recently proposed but not yet developed targets for NB therapy. In this review, we discuss the recently proposed molecular targets that are in clinical trials and, in particular, those that are not yet explored in the clinic. We focus on the selection of these molecular targets for which promising in vitro and in vivo results have been obtained by silencing/inhibiting them. In addition, these selected targets are involved at least in one of the NB tumorigenic processes: proliferation, anti-apoptosis, angiogenesis and/or metastasis. In particular, we will review a recently proposed target, the microtubule-associated protein (MAP) encoded by doublecortin-like kinase gene (DCLK1). DCLK1-derived MAPs are crucial for proliferation and survival of neuroblasts and are highly expressed not only in NB but also in other tumours such as gliomas. Additionally, we will discuss neuropeptide $\mathrm{Y}$, its $\mathrm{Y} 2$ receptor and cathepsin $L$ as examples of targets to decrease angiogenesis and metastasis of NB. Furthermore, we will review the micro-RNAs that have been proposed as therapeutic targets for NB. Detailed investigation of these not yet developed targets as well as exploration of multi-target approaches might be the key to a more effective NB therapy, i.e. increasing specificity, reducing toxicity and avoiding long-term side effects.
\end{abstract}

Endocrine-Related Cancer (2011) 18 R213-R231

\section{Introduction}

The most common solid extracranial neoplasm in children is neuroblastoma (NB). It is also the most common childhood cancer diagnosed in children before the age of 1 year (Maris et al. 2007). NB is characterised by a broad range of clinical behaviour. The International Neuroblastoma Staging System (INSS) merges some characteristics of the previously used Pediatric Oncology Group and Children's Cancer Group systems and has identified distinct prognostic stages (1, 2A, 2B, 3, 4 and 4S; Brodeur et al. 1993). Based on the INSS stage, group age and tumour biology, patients can be assigned to a low-, intermediate- or high-risk group (Brodeur et al. 1993, Haase et al. 1999). The biological features of the tumour for the assignment to one of these three groups include
MYCN status (Brodeur et al. 1984), International Neuroblastoma Pathologic Classification score (Shimada et al. 1999) and tumour DNA index (Look et al. 1991), which describes the number of chromosomes in the tumour cells compared to normal cells. The therapy applied to NB patients depends on the risk category (Haase et al. 1999). Low-risk patients can be cured with surgery or just observed without receiving treatment (Park et al. 2008). Intermediate-risk patients are usually treated with surgery and chemotherapy (Modak \& Cheung 2010). High-risk NB is treated with surgery, intensive chemotherapy, radiation therapy, bone marrow or haematopoietic stem cell transplantation and targeted biologic therapies with 13-cis-retinoic acid and immunotherapy. The immunotherapy involves the administration of cytokines 
such as granulocyte-macrophage colony-stimulating factor (GM-CSF) and interleukin-2 (IL2) and/or administration of monoclonal antibodies that target GD2, an NB surface antigen (Johnson et al. 2007, Park et al. 2008, Castel et al. 2010, Modak \& Cheung 2010). Despite advances in treatment, significant complications remain, particularly in patients with high-risk NB. First, a majority of the patients suffers remission relapse in bone/bone marrow or, less commonly, in soft tissue. Secondly, isolated relapses in the central nervous system are also being detected in some patients (Modak \& Cheung 2010).

Clearly, improved therapeutic approaches are needed to increase specificity, reduce toxicity and avoid the long-term side effects. Therapeutics that selectively inhibits the activity of a single molecule has been proposed. Ideally, the targeted molecule plays an essential role in the genesis and/or maintenance of the tumour of interest such that its partial or complete inhibition is cytotoxic to tumour cells resulting in tumour regression in the absence of any secondary effects. Very few molecules with such ideal characteristics have been identified and drugged in cancers in general, and especially in paediatric cancers such as NB. Several molecule-targeted therapeutics are under investigation in the pre-clinical or clinical phase of drug development and promising results have been obtained (Fong \& Park 2009, Wagner \& Danks 2009, George et al. 2010, Modak \& Cheung 2010). Here, we provide an overview of some of the targets that are presently being studied in the clinic (Table 1) and particular attention is paid to the most recently proposed molecular targets for NB therapy that have not yet reached the clinic (Tables 2 and 3), which might be crucial for the origin and progression of NB and possibly also for other cancer types. In addition, we will discuss multi-target therapeutic approaches for NB and provide future perspectives in this field for the coming years.

\section{Origin and progression of NB}

NB derives from multi-potent neural crest (NC) cells. NB tumours are formed as a result of genetic mutation and/or changes in epigenetic factors responsible for the correct programming of the NC cells (Fig. 1; Gershon et al. 2005). NC cells migrate from the neural tube to generate the primordial of the sympathetic chain along the abdominal aorta (Nakagawara 2005). During this process, several abnormalities might occur that contribute to tumorigenesis, including loss of control of cell proliferation, differentiation or apoptosis. The NB cell transcriptome reflects its origin in neuronal crest-derived tissues (Nakagawara 2005). Other neuroectodermal tumours have similar origin and are also pluripotent, proliferative and migratory, like NC cells. These are neurofibroma, schwannoma, malignant nerve sheath tumour, melanoma, medulloblastoma, supratentorial primitive neuroectodermal tumour and Ewing's sarcoma (Pomeroy et al. 2002, Gershon et al. 2005).

Several genes are regulated in an orchestrated manner to drive the correct differentiation of $\mathrm{NC}$ cells into sympathetic neurons (Fig. 1). Some of these genes, such as PHOX2A, PHOX2B, NTRK2 (TrkB) (Hallbook et al. 1995, Nakagawara 2001) and MYCN (Zimmerman et al. 1986), are up-regulated in high-risk NBs as well as in medulloblastoma (Nakagawara 2004, Nakagawara \& Ohira 2004, Harel et al. 2010, Swartling et al. 2010). MYCN promotes proliferation and prevents the differentiation of neuronal progenitors during embryonic development (Alam et al. 2009). The Notch pathway also seems to play a role in keeping the sympathetic precursors in a proliferative state and to inhibit neuronal differentiation (Tsarovina et al. 2008). Moreover, several of these genes are highly specific for NB, enhancing the possibility for accurate diagnosis and identification of therapeutic targets (Cheung 2005). Understanding the processes involved in NB progression and maintenance is of great importance for an effective NB therapy. These processes include cell proliferation, survival, angiogenesis, invasion and metastasis.

\section{Targeting NB}

Identifying and validating new therapeutic targets for enhanced treatment of children with high-risk NB is of main priority. Understanding the mechanisms underlying high-risk NB may allow the discovery of novel potential targets. Exploring the pathophysiological and mechanistic action of existing therapeutic agents are two other routes that have been followed for finding new targets. However, the progress in those research fields can be slow. Therefore, there is strong incentive to seek shortcuts based on the use of novel technologies to select and validate new targets, such as microarrays, next-generation sequencing technologies, phosphoproteomics and transcriptome sequencing, among others.

One strategy for target identification in NB is investigating the mechanisms of origin and maintenance of NB and the genes, micro-RNAs (miRNAs) and proteins that play a key role in those processes. Here, we provide an overview of several coding genes, miRNAs and proteins that might play a role in NB 
Table 1 Proposed target genes for neuroblastoma therapy that are under investigation in the clinic

\begin{tabular}{|c|c|c|c|c|}
\hline $\begin{array}{l}\text { Gene } \\
\text { symbols }\end{array}$ & Names & Function/processes & Compound(s) & Reference(s) \\
\hline$A K T 1$ & $\begin{array}{l}\text { v-akt murine thymoma viral } \\
\text { oncogene homologue } 1\end{array}$ & $\begin{array}{l}\text { Cell growth/proliferation, } \\
\text { apoptosis }\end{array}$ & $\begin{array}{l}\text { A-443654, perifosine } \\
\quad(\mathrm{KRX}-0401)\end{array}$ & $\begin{array}{l}\text { Opel et al. (2007), } \\
\text { LoPiccolo et al. (2008), } \\
\text { Li et al. (2011) }\end{array}$ \\
\hline$A L K$ & $\begin{array}{l}\text { Anaplastic lymphoma } \\
\text { receptor tyrosine kinase }\end{array}$ & $\begin{array}{l}\text { Transmembrane receptor } \\
\text { protein tyrosine kinase } \\
\text { activity, development } \\
\text { of the brain }\end{array}$ & PF-2341066 & $\begin{array}{l}\text { George et al. (2008), } \\
\text { Mosse et al. (2008), } \\
\text { Ogawa et al. (2011) }\end{array}$ \\
\hline$A \cup R K A$ & Aurora kinase $\mathrm{A}$ & Cell cycle regulation & MLN8237 & $\begin{array}{l}\text { Wagner \& Danks (2009), } \\
\text { George et al. (2010), } \\
\text { Carol et al. (2011) }\end{array}$ \\
\hline$B C L 2$ & B-cell CLL/lymphoma 2 & Anti-apoptosis & Obatoclax & $\begin{array}{l}\text { Dole et al. (1994), } \\
\text { Rheingold et al. (2007) }\end{array}$ \\
\hline CTLA4 & $\begin{array}{l}\text { Cytotoxic T-lymphocyte- } \\
\text { associated protein } 4\end{array}$ & Immune response, apoptosis & Ipilimumab (MDX-010) & $\begin{array}{l}\text { Contardi et al. (2005), } \\
\text { Modak \& Cheung (2010) }\end{array}$ \\
\hline$E G F R$ & $\begin{array}{l}\text { Epidermal growth factor } \\
\text { receptor }\end{array}$ & $\begin{array}{l}\text { Cell proliferation, cell-cell } \\
\text { adhesion, apoptosis }\end{array}$ & Gefitinib (ZD1839) & $\begin{array}{l}\text { Modak \& Cheung (2010), } \\
\text { Furman et al. (2011) }\end{array}$ \\
\hline$H D A C$ & Histone deacetylase & $\begin{array}{l}\text { Transcriptional regulation, cell } \\
\text { cycle progression and } \\
\text { development }\end{array}$ & $\begin{array}{l}\text { Valproic acid, } \\
\text { Vorinostat }\end{array}$ & $\begin{array}{l}\text { Coffey et al. (2001), } \\
\text { George et al. (2010) }\end{array}$ \\
\hline HSP90AA1 & $\begin{array}{l}\text { Heat-shock protein } \\
90 \text { kDa alpha (cytosolic), } \\
\text { class A member } 1\end{array}$ & $\begin{array}{l}\text { Signal transduction, protein } \\
\text { folding, protein degradation } \\
\text { cell growth }\end{array}$ & 17-AAG & $\begin{array}{l}\text { Kang et al. (2006), } \\
\text { Furchert et al. (2007), } \\
\text { George et al. (2010) }\end{array}$ \\
\hline IGF1R & IGF1 receptor & $\begin{array}{l}\text { Anti-apoptotic, tyrosine kinase } \\
\text { activity }\end{array}$ & $\begin{array}{r}\text { NVP-AEW541, EM164, } \\
\text { SCH71745, IMC-A12 }\end{array}$ & $\begin{array}{l}\text { Liu et al. (1998), } \\
\text { Wagner \& Danks (2009) }\end{array}$ \\
\hline$K D R$ & $\begin{array}{l}\text { Kinase insert domain } \\
\text { receptor (a type III } \\
\text { receptor tyrosine kinase) }\end{array}$ & $\begin{array}{l}\text { Growth factor, endothelial } \\
\text { proliferation, survival, } \\
\text { migration, tubular morpho- } \\
\text { genesis and sprouting }\end{array}$ & $\begin{array}{c}\text { Bevacizumab, sunitinib, } \\
\text { cediranib (AZD2171) }\end{array}$ & $\begin{array}{l}\text { Segerstrom et al. (2006), } \\
\text { Sims et al. (2008), } \\
\text { Morton et al. (2011) }\end{array}$ \\
\hline mTOR & $\begin{array}{l}\text { Mechanistic target of } \\
\text { rapamycin (serine/ } \\
\text { threonine kinase) }\end{array}$ & $\begin{array}{l}\text { Cell cycle, proliferation, cellular } \\
\text { responses to stresses }\end{array}$ & $\begin{array}{l}\text { Rapamycin, everolimus, } \\
\text { temsirolimus, } \\
\text { AP23573 }\end{array}$ & $\begin{array}{l}\text { LoPiccolo et al. (2008), } \\
\text { Fulda (2009), } \\
\text { Wagner \& Danks (2009) }\end{array}$ \\
\hline NTRK2 & $\begin{array}{l}\text { Neurotrophic tyrosine } \\
\text { kinase, receptor, type } 2\end{array}$ & $\begin{array}{l}\text { Cell signalling, } \\
\text { cell differentiation }\end{array}$ & CEP-701 (KT-6587) & Evans et al. $(1999,2001)$ \\
\hline PDK1 & $\begin{array}{l}\text { Pyruvate dehydrogenase } \\
\text { kinase, isozyme } 1\end{array}$ & $\begin{array}{l}\text { Carbohydrate and pyruvate } \\
\text { metabolic processes }\end{array}$ & OSU-03012 & Fulda (2009) \\
\hline PIКЗCA & $\begin{array}{l}\text { Phosphoinositide-3- } \\
\text { kinase, catalytic, alpha } \\
\text { polypeptide }\end{array}$ & $\begin{array}{l}\text { Anti-apoptosis, glucose } \\
\text { metabolism process, signal } \\
\text { transduction }\end{array}$ & $\begin{array}{l}\text { GDC-0941, } \\
\text { NVP-BEZ235 }\end{array}$ & LoPiccolo et al. (2008) \\
\hline TNFRSF10B & $\begin{array}{l}\text { Tumour necrosis factor } \\
\text { receptor superfamily, } \\
\text { member } 10 \mathrm{~b}\end{array}$ & Apoptosis & $\begin{array}{l}\text { Lexatumumab } \\
\text { (ETR2-ST01) }\end{array}$ & $\begin{array}{l}\text { Zhang et al. (2007b), } \\
\text { Modak \& Cheung (2010) }\end{array}$ \\
\hline
\end{tabular}

Gene symbols and names are in agreement with HUGO Gene Nomenclature Committee even when the nomenclature used in the references is different.

origin and progression and that have been proposed as therapeutic targets. This overview is subdivided into three separate sections: 1) molecular targets under investigation in the clinic, 2) proposed molecular targets not yet explored in the clinic and 3) miRNAs as targets for NB therapy.

\section{Molecular targets under investigation in the clinic}

The field of NB therapy is progressing and several of the proposed targets have reached pre-clinical and clinical studies in the last years (Table 1). Those molecular targets include tyrosine kinase receptors that have been implicated in NB pathology, such as anaplastic lymphoma kinase (ALK), the insulin-like growth factor 1 receptor (IGF1R) and tropomyosin receptor kinase (TRK). Inhibition of Aurora A kinase (AURKA) and mechanistic target of rapamycin (mTOR) pathway are other examples of approaches that are under investigation in the clinic and that we will review here.

ALK was originally identified as an oncogene in lymphoma (Shiota et al. 1994) but is now known to 
Table 2 Proposed target genes for neuroblastoma therapy

\begin{tabular}{|c|c|c|c|}
\hline $\begin{array}{l}\text { Gene } \\
\text { symbols }\end{array}$ & Names & Function/processes & Reference(s) \\
\hline BCL6 & B-cell CLL/lymphoma 6 & Cell proliferation, differentiation, apoptosis & Chamdin et al. (2009) \\
\hline BIRC5 & Baculoviral IAP repeat-containing 5 & Apoptosis, cell cycle & $\begin{array}{l}\text { Islam et al. }(2000 b) \\
\text { Duffy et al. }(2007)\end{array}$ \\
\hline CASP8 & $\begin{array}{l}\text { Caspase } 8 \text {, apoptosis-related } \\
\text { cysteine peptidase }\end{array}$ & Apoptosis, cell adhesion and metastasis & McKee \& Thiele (2006) \\
\hline CCND1 & Cyclin D1 & Cell cycle, differentiation & Molenaar et al. $(2008,2010)$ \\
\hline$C D 44$ & CD44 molecule (Indian blood group) & Cell adhesion and metastases & Yoon \& Danks (2009) \\
\hline$C D K 2$ & Cyclin-dependent kinase 2 & Cell cycle, DNA replication & Molenaar et al. (2009) \\
\hline CENPE & Centromere protein $\mathrm{E}$ & Cell cycle & Balamuth et al. (2010) \\
\hline CRABP2 & $\begin{array}{l}\text { Cellular retinoic acid binding } \\
\text { protein } 2\end{array}$ & $\begin{array}{l}\text { Epidermis development, signal transduction, } \\
\text { retinoic acid metabolic process }\end{array}$ & Itoh et al. (2010) \\
\hline CTSL1 & Cathepsin L1 & $\begin{array}{l}\text { Proliferation, apoptosis, angiogenesis, inva- } \\
\text { sion and metastasis }\end{array}$ & $\begin{array}{l}\text { Zheng et al. (2009), } \\
\text { Colella et al. (2010), } \\
\text { Lankelma et al. (2010) }\end{array}$ \\
\hline$D C L K 1$ & Doublecortin-like kinase 1 & $\begin{array}{l}\text { Cell proliferation, survival, neuronal cell } \\
\text { migration, neurogenesis }\end{array}$ & $\begin{array}{l}\text { Shu et al. (2006), } \\
\text { Vreugdenhil et al. (2007), } \\
\text { Verissimo et al. (2010) }\end{array}$ \\
\hline DIABLO & $\begin{array}{l}\text { Diablo, IAP-binding mitochondrial } \\
\text { protein }\end{array}$ & Apoptosis, neuroblastoma progression & Wolf et al. (2010) \\
\hline DUSP26 & $\begin{array}{l}\text { Dual specificity phosphatase } 26 \\
\text { (putative) }\end{array}$ & Protein dephosphorylation & Shang et al. (2010) \\
\hline EPAS1 & Endothelial PAS domain protein 1 & $\begin{array}{l}\text { Keeps tumour-initiating cells in a undifferen- } \\
\text { tiated state }\end{array}$ & $\begin{array}{l}\text { Pietras et al. (2009), } \\
\text { Qing et al. (2010) }\end{array}$ \\
\hline GCLC & $\begin{array}{l}\text { Glutamate-cysteine ligase, } \\
\text { catalytic subunit }\end{array}$ & Glutamate-cysteine ligase, apoptosis & de Tudela et al. (2010) \\
\hline GSK3B & Glycogen synthase kinase 3 beta & $\begin{array}{l}\text { Neuronal cell development, hippocampus } \\
\text { development, glycogen metabolic process }\end{array}$ & $\begin{array}{l}\text { Li et al. (2010), } \\
\text { Dickey et al. (2011) }\end{array}$ \\
\hline HIF1A & $\begin{array}{l}\text { Hypoxia inducible factor } 1 \text { alpha } \\
\text { subunit (basic helix-loop-helix } \\
\text { transcription factor) }\end{array}$ & $\begin{array}{l}\text { Differentiation of neural crest cells, modu- } \\
\text { lation of energy metabolism in cancer }\end{array}$ & $\begin{array}{l}\text { Yeo et al. (2003), } \\
\text { Nakagawara \& Ohira (2004) }\end{array}$ \\
\hline Id2 & $\begin{array}{l}\text { Inhibitor of DNA binding } 2 \text {, dominant } \\
\text { negative helix-loop-helix protein }\end{array}$ & $\begin{array}{l}\text { Differentiation of neural crest cells, transcrip- } \\
\text { tion factor }\end{array}$ & $\begin{array}{l}\text { Lasorella et al. (2002), } \\
\text { Nakagawara (2004) }\end{array}$ \\
\hline IGFBP5 & IGF binding protein 5 & $\begin{array}{l}\text { Regulation of cell growth, signal transduction, } \\
\text { apoptosis, cell migration }\end{array}$ & Tanno et al. (2005) \\
\hline$\angle D H A$ & Lactate dehydrogenase $\mathrm{A}$ & $\begin{array}{l}\text { Anaerobic glycolysis, oxidation-reduction } \\
\text { process }\end{array}$ & Qing et al. (2010) \\
\hline LGALS1 & $\begin{array}{l}\text { Lectin, galactoside binding, } \\
\text { soluble, } 1\end{array}$ & $\begin{array}{l}\text { Cell proliferation, migration, differentiation, } \\
\text { apoptosis }\end{array}$ & Cimmino et al. (2009) \\
\hline MCL1 & $\begin{array}{l}\text { Myeloid cell leukaemia sequence } 1 \\
\quad \text { (BCL2-related) }\end{array}$ & Apoptosis, differentiation & Lestini et al. (2009) \\
\hline METAP2 & Methionine aminopeptidase 2 & Angiogenesis & Shusterman \& Maris (2005) \\
\hline MIF & $\begin{array}{l}\text { Macrophage migration inhibitory } \\
\text { factor (glycosylation-inhibiting } \\
\text { factor) }\end{array}$ & $\begin{array}{l}\text { Cell proliferation, negative regulator of apop- } \\
\text { tosis, negative regulator of cell cycle arrest }\end{array}$ & Ren et al. (2006) \\
\hline NME1 & $\begin{array}{l}\text { Non-metastatic cells } 1 \text {, protein } \\
(\mathrm{NM} 23 \mathrm{~A}) \text { expressed in }\end{array}$ & $\begin{array}{l}\text { Cell adhesion, metastasis, cell differentiation, } \\
\text { negative regulation of apoptosis }\end{array}$ & $\begin{array}{l}\text { van Noesel \& Versteeg (2004), } \\
\text { Tee et al. (2006) }\end{array}$ \\
\hline NME2 & $\begin{array}{l}\text { Non-metastatic cells } 2 \text {, protein } \\
(\mathrm{NM} 23 \mathrm{~A}) \text { expressed in }\end{array}$ & $\begin{array}{l}\text { Cell adhesion, negative regulation of apopto- } \\
\text { sis }\end{array}$ & van Noesel \& Versteeg (2004) \\
\hline$N P Y$ & Neuropeptide $Y$ & Tumour cell proliferation, angiogenesis & Lu et al. (2010) \\
\hline NPY2R & Neuropeptide $Y$ receptor $Y 2$ & Tumour cell proliferation, angiogenesis & Lu et al. (2010) \\
\hline$P A X 3$ & Paired box 3 & $\begin{array}{l}\text { Apoptosis, regulation of transcription, } \\
\text { multi-cellular organism development }\end{array}$ & Gershon et al. (2005) \\
\hline$P A X 7$ & Paired box 7 & Anti-apoptosis, differentiation, neuronal fate & Gershon et al. (2005) \\
\hline pLK1 & Polo-like kinase 1 & $\begin{array}{l}\text { Cell cycle, cell proliferation, G2/M transition } \\
\text { DNA damage checkpoint }\end{array}$ & Hu et al. (2009) \\
\hline PRAF2 & PRA1 domain family, member 2 & $\begin{array}{l}\text { Protein transport, L-glutamate transport, } \\
\text { apoptosis }\end{array}$ & Geerts et al. (2007) \\
\hline
\end{tabular}




\begin{tabular}{|c|c|c|c|}
\hline $\begin{array}{l}\text { Gene } \\
\text { symbols }\end{array}$ & Names & Function/processes & Reference(s) \\
\hline PTGS2 & $\begin{array}{l}\text { Prostaglandin-endoperoxide } \\
\text { synthase } 2 \text { (prostaglandin G/H } \\
\text { synthase and cyclooxygenase) }\end{array}$ & $\begin{array}{l}\text { Cell cycle, apoptosis, cell migration, } \\
\text { angiogenesis }\end{array}$ & Kaneko et al. (2009) \\
\hline PTK2 & PTK2 protein tyrosine kinase 2 & $\begin{array}{l}\text { Regulates both cellular adhesion and apop- } \\
\text { tosis }\end{array}$ & Beierle et al. (2010) \\
\hline$R A C 1$ & $\begin{array}{l}\text { Ras-related C3 botulinum toxin sub- } \\
\text { strate } 1 \text { (rho family, small GTP- } \\
\text { binding protein Rac1) }\end{array}$ & $\begin{array}{l}\text { Cytoskeleton organisation, cell proliferation, } \\
\text { migration, cell survival }\end{array}$ & Lazer \& Katzav (2011) \\
\hline$R A N$ & RAN, member RAS oncogene family & Regulator in the nervous system, cell cycle & Tietze et al. (2008) \\
\hline SOX10 & $\begin{array}{l}\text { SRY }(\text { sex determining } \\
\text { region } Y) \text {-box } 10\end{array}$ & $\begin{array}{l}\text { Embryonic development and cell fate, neural } \\
\text { crest and peripheral nervous system } \\
\text { development }\end{array}$ & Gershon et al. (2005) \\
\hline TFAP2A & Transcription factor AP-2 alpha & $\begin{array}{l}\text { Ectoderm development, skeletal system } \\
\text { morphogenesis }\end{array}$ & Gershon et al. (2005) \\
\hline TLR9 & Toll-like receptor 9 & $\begin{array}{l}\text { Positive regulation of JNK cascade and JUN } \\
\text { kinase activity, positive regulation of } \\
\text { inflammatory response }\end{array}$ & Brignole et al. (2010) \\
\hline TOP2A & $\begin{array}{l}\text { Topoisomerase (DNA) II alpha } \\
170 \mathrm{kDa}\end{array}$ & Apoptosis, DNA repair and replication & Glynn et al. (2010) \\
\hline TP73 & Tumour protein $\mathrm{p} 73$ & $\begin{array}{l}\text { Differentiation of neural crest cells, apoptosis, } \\
\text { migration }\end{array}$ & $\begin{array}{l}\text { Moll \& Slade (2004), } \\
\text { Wolter et al. (2010) }\end{array}$ \\
\hline UGCG & $\begin{array}{l}\text { UDP-glucose ceramide } \\
\text { glucosyltransferase }\end{array}$ & $\begin{array}{l}\text { Lipid and glucosylceramide biosynthetic } \\
\text { process, keratinocyte differentiation }\end{array}$ & Barth et al. (2010) \\
\hline YBX1 & $\mathrm{Y}$ box binding protein 1 & $\begin{array}{l}\text { Cell proliferation, regulator of transcription, } \\
\text { metastasis }\end{array}$ & Wachowiak et al. (2010) \\
\hline
\end{tabular}

Gene symbols and names are in agreement with HUGO Gene Nomenclature Committee even when the nomenclature used in the references is different.

be preferentially expressed in neuronal cells at late embryonic stages. Activation of ALK induces cell growth and neurite outgrowth that is mediated by the MAPK pathway (Motegi et al. 2004). Mutated forms of ALK have been identified in high-risk NB (Wagner \& Danks 2009, George et al. 2010). In fact, around $10 \%$ of NB tumours are estimated to have an ALK mutation (Fong \& Park 2009). Gain or amplification of $A L K$ has been associated with aggressive clinic phenotype (George et al. 2010) and specific block of ALK results in growth inhibition and increases apoptosis (Fong \& Park 2009). Therefore, recent interests in targeting ALK for NB therapy have arisen and several ALK inhibitors have been developed and are under investigation (Ardini et al. 2010). First clinical trials with ALK inhibitors show promising results for the treatment of non-small cell lung cancer (http:// clinicaltrials.gov \#NCT00585195) in which ALK signalling is deranged (Soda et al. 2007). Also, a phase I/II study, using PF-02341066 as an ALK inhibitor (Table 1), is presently ongoing for NB (http://clinicaltrials.gov \#NCT00939770).

TRK, originally identified as an oncogene (MartinZanca et al. 1986), is now known as the high-affinity receptor for nerve growth factor and as such is crucially involved in the growth, differentiation and apoptosis of neuronal cells in both the central and the peripheral nervous system (for review, see Nakagawara et al. (2001)). High expression levels of TRK have been correlated with poor NB outcome (Nakagawara et al. 1993) and chemotherapy resistance (Ho et al. 2002). Since its discovery in 1986 (Martin-Zanca et al. 1986), TRK has been a focus of intense pharmaceutical experimentation and several TRK-blocking small compounds, such as CEP-701, have been developed. It has been shown that blocking TRK using CEP-701 results in induction of apoptosis (Evans et al. 1999) and growth inhibition of human NB xenografts in nude mice (Evans et al. 2001). Presently, a phase I trial is ongoing in patients with recurrent or refractory highrisk NB (http://clinicaltrials.gov \#NCT00084422).

IGF1R is involved in the regulation of cell proliferation, survival, differentiation and transformation (Bahr \& Groner 2005). IGF1R is highly expressed in NB (El-Badry et al. 1989) and activation of IGF1R induces the expression of MYCN (Misawa et al. 2000). The expression level of IGF1R has been correlated with tumorigenicity and metastasis 
Table 3 Potential micro-RNAs as targets for neuroblastoma therapy

\begin{tabular}{|c|c|c|c|c|}
\hline miRNA & Validated target(s) & Function/processes & Types & Reference(s) \\
\hline miR-17-5p-92 cluster & $\begin{array}{l}\text { TGF } \beta \text {-signalling, CDKN1A } \\
\text { (p21); BCL2L11 (Bim) }\end{array}$ & $\begin{array}{l}\text { Cell proliferation, cell } \\
\text { adhesion }\end{array}$ & Oncogene & $\begin{array}{l}\text { Fontana et al. (2008), } \\
\text { Mestdagh et al. (2010) }\end{array}$ \\
\hline miR-34a & NMYC, BCL-2, E2F3 & $\begin{array}{l}\text { Cell cycle progression, } \\
\text { apoptosis, DNA repair } \\
\text { and angiogenesis }\end{array}$ & $\begin{array}{l}\text { Tumour } \\
\text { suppressor }\end{array}$ & $\begin{array}{l}\text { Welch et al. (2007), } \\
\text { Cole et al. (2008), } \\
\text { Wei et al. (2008) }\end{array}$ \\
\hline miR-184 & AKT2 & $\begin{array}{l}\text { Neural differentiation } \\
\text { and/or apoptosis }\end{array}$ & $\begin{array}{l}\text { Tumour } \\
\text { suppressor }\end{array}$ & $\begin{array}{l}\text { Foley et al. (2010), } \\
\text { Tivnan et al. (2010) }\end{array}$ \\
\hline $\operatorname{miR}-380-5 p$ & p53 & Apoptosis & Oncogene & Swarbrick et al. (2010) \\
\hline $\operatorname{miR}-9$ & $\begin{array}{l}\text { E-cadherin, tropomyosin- } \\
\text { related kinase } C\end{array}$ & $\begin{array}{l}\text { Angiogenesis, } \\
\text { metastasis }\end{array}$ & Oncogene & $\begin{array}{l}\text { Laneve et al. (2007), } \\
\text { Ma et al. (2010), } \\
\text { Khew-Goodall \& } \\
\text { Goodall (2010) }\end{array}$ \\
\hline $\operatorname{miR}-125 a$ & $\begin{array}{l}\text { Bmf, tropomyosin-related } \\
\text { kinase C }\end{array}$ & Cell proliferation, apoptosis & Oncogene & Laneve et al. (2007) \\
\hline $\operatorname{miR}-125 b$ & $\begin{array}{l}\text { Bmf, tropomyosin-related } \\
\text { kinase C }\end{array}$ & Cell proliferation, apoptosis & Oncogene & Laneve et al. (2007) \\
\hline miR-152 & CHUK, CUL5 and GADD45A & $\begin{array}{l}\text { Neuroblast differentiation, } \\
\text { migration/invasion and } \\
\text { apoptosis }\end{array}$ & Oncogene & Ragusa et al. (2010) \\
\hline miR-338 & PTPRT & $\begin{array}{l}\text { Neuroblast differentiation } \\
\text { and apoptosis }\end{array}$ & Oncogene & Ragusa et al. (2010) \\
\hline miR-200B & ZEB1 & $\begin{array}{l}\text { Neuroblast differentiation, } \\
\text { migration/invasion and } \\
\text { apoptosis }\end{array}$ & $\begin{array}{l}\text { Tumour } \\
\text { suppressor }\end{array}$ & Ragusa et al. (2010) \\
\hline
\end{tabular}

(George et al. 2010). Blocking IGF1R with anti-IGF1R antibodies resulted in the inhibition of NB cells growth and tumour regression in NB xenograft mouse models (Geoerger et al. 2010). The anti-IGF1R monoclonal antibody (IMC-A12) is presently under investigation in phase II trial (http://clinicaltrials.gov \#NCT00 831844).

AURKA is a serine/threonine kinase, which stabilises the microtubule at the spindle pole during chromosome segregation. Therefore, AURKA is essential for G2-M progression and its inhibition results in cell cycle arrest and apoptosis (Hirota et al. 2003, George et al. 2010). AURKA is overexpressed in multiple tumours, including $\mathrm{NB}$, and amplification of AURKA gene has also been observed in NB cells (Otto et al. 2009). In phase I trials, promising results have also been obtained with AURKA inhibitor MLN8237 (Wagner \& Danks 2009, George et al. 2010, Carol et al. 2011). A phase II trial is ongoing (http:// clinicaltrials.gov \#NCT01154816).

Inhibition of mTOR pathway, targeting phosphatidylinositol 3-kinases, IGF1R, mTOR and/or vascular endothelial growth factor (VEGF), is under investigation as well (Kang et al. 2008, George et al. 2010). mTOR pathway is involved in the regulation of cell growth and proliferation (Sarbassov et al. 2005). Notably, the simultaneous inhibition of different proteins (e.g. mTOR and IGF1R) seems to be a more effective therapeutic approach than targeting them individually (Coulter et al. 2008). For instances, in phase I trial (http://clinicaltrials.gov \#NCT01204450), mTOR is targeted using temsirolimus in combination with valproic acid which targets histone deacetylase.

In Table 1, we provide a general overview of the target genes/proteins that are under investigation in the clinic. For further reading on these promising molecular targets for NB therapy, we refer to excellent reviews (Fong \& Park 2009, Wagner and Danks 2009, George et al. 2010, Modak \& Cheung 2010).

\section{Proposed molecular targets not yet explored in the clinic}

Several interesting targets (genes/proteins) have recently been proposed for NB therapy but have not reached the clinic yet (Table 2). However, they might be the targets to consider for future successful NB therapy. They include, for example, cyclin-dependent kinase 2 (CDK2), which is involved in DNA replication and cell cycle. CDK2 is a regulator of S-phase progression (Shapiro 2006). Inactivation of CDK2 has been shown to be synthetically lethal to MYCN-amplified NB cells and is therefore an interesting molecular target (Molenaar et al. 2009). The anti-apoptotic regulatory protein survivin 


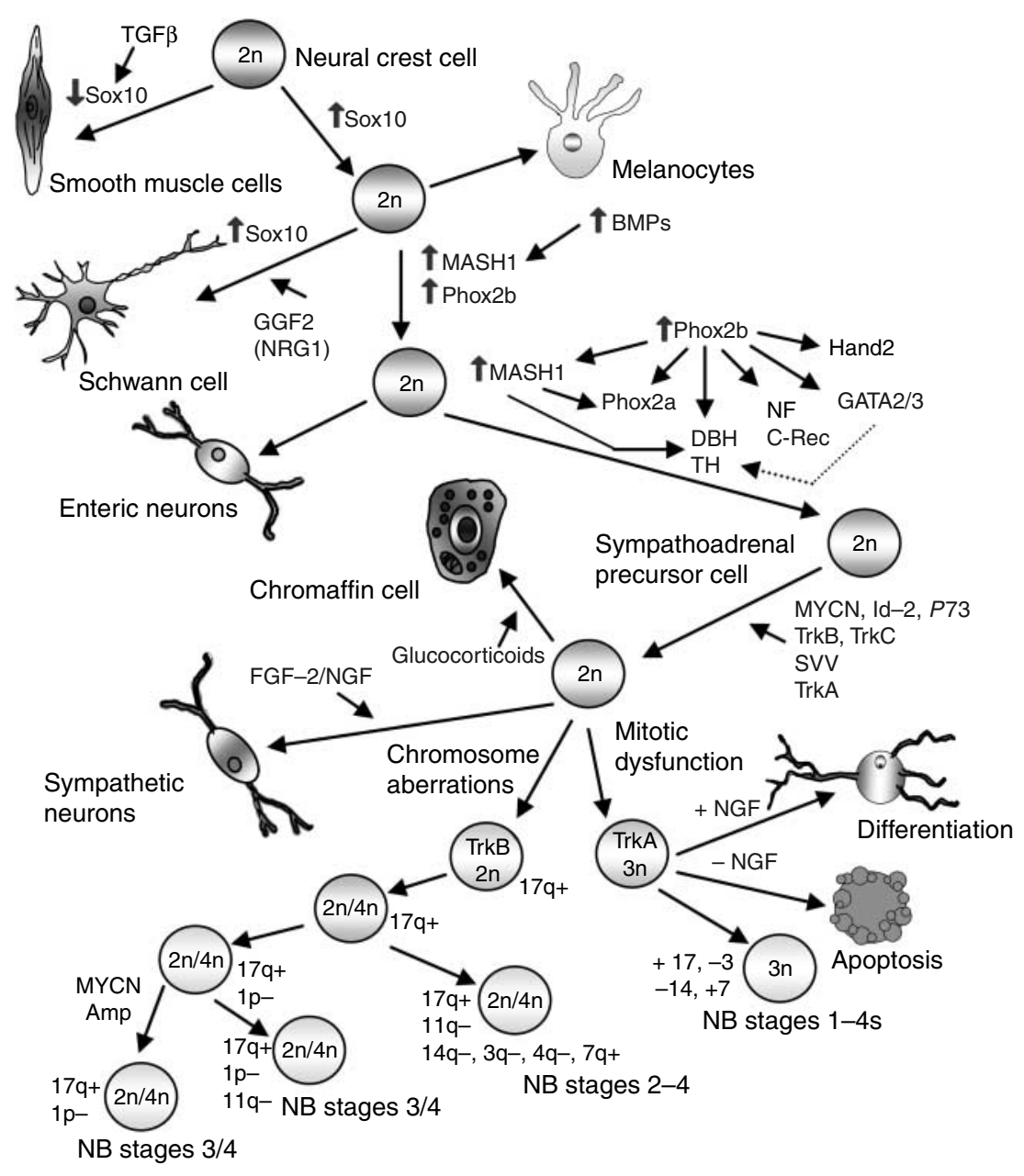

Figure 1 Development of the lineages derived from neural crest cells and the origin of the different stages of neuroblastoma (NB). This figure is based on the information provided by Maris \& Matthay (1999), Mora \& Gerald (2004), Nakagawara \& Ohira (2004), and Huber (2006). Full colour version of this figure available via http://dx.doi.org/10.1530/ERC-11-0251.

(baculoviral IAP repeat-containing 5 (BIRC5)), which is selectively expressed in the most common human cancers but not in normal adult tissues, has been shown to be overexpressed in NB (Islam et al. 2000a,b). Hence, survivin has been proposed as NB target as well (Duffy et al. 2007). Cyclin D1 (CCND1) is up-regulated in NB compared with other types of tumours and normal tissue (Molenaar et al. 2010). GATA3 was found to be implicated in cyclin D1 overexpression in NB (Molenaar et al. 2010). Silencing of the proposed therapeutic target cyclin D1 causes the differentiation of NB cells (Molenaar et al. 2008). Another proposed target, lactase dehydrogenase A, plays a role in anaerobic glycolysis, which is known to be a crucial process in providing energy for NB tumours (Qing et al. 2010). Some examples of other cancer types that also expressed the proposed targets for NB therapy are shown in Supplementary Table 1, see section on supplementary data given at the end of this article.

For further detailed information, we selected some proposed genes/proteins that have been shown to be involved in at least one of the different NB tumorigenic processes: proliferation, anti-apoptosis, angiogenesis and/or metastasis. In addition, for these genes/proteins, promising in vitro and in vivo results were obtained by silencing/inhibiting them. We recently proposed to target doublecortin-like kinase ( $D C L K l)$ to inhibit NB proliferation and induce apoptosis (Verissimo et al. 2010). In addition, neuropeptide Y (NPY) and its Y2 receptor (NY2R) were selected as examples of antiangiogenesis targets (Lu et al. 2010). The high expression levels of the sympathetic neurotransmitter NPY correlates with MYCN amplification and with poor clinic outcome (Dötsch et al. 1998). Furthermore, 
for NB invasion and metastasis, cathepsin L was chosen for further reviewing (Lankelma et al. 2010). Cathepsin L is also involved in the development of drug resistance (Zheng et al. 2004).

\section{Inhibiting NB proliferation and survival: DCLK1}

Several proteins have been shown to play a crucial role in NB proliferation and survival, MYCN being probably the best known and characterised. In addition, there are a number of genes that have been reported as regulators in the neuronal system, such as small GTPase $R A B 6 B$, cell recognition molecule Caspr2 (CNTNAP2), neurexophilin (Nxphl) and DCLK1 that are also expressed in NB (Nakagawara \& Ohira 2004). Of particular interest are members of the $D C X$ gene family like DCLK1 (Coquelle et al. 2006, Reiner et al. 2006). By virtue of alternative splicing, the DCLK1 gene encodes for several microtubule-binding protein (MAP). MAPs have been considered as potential targets for cancer therapy. However, since most MAPs are not specifically expressed in cancer cells, high toxicity due to the treatment has been reported. In contrast, DCLK1containing microtubule-binding domains are particularly highly expressed in neuroblasts and NBs but not in other cell types, suggesting that targeting these MAPs is a highly interesting potential therapeutic approach with low cytotoxic side effects.

The $D C L K 1$ gene encodes numerous splice variants. The main splice variants are DCL, DCLK-long, DCLKshort and calcium/calmodulin-dependent protein kinase (CaMK)-related peptide (CARP; Vreugdenhil et al. 2001, Burgess \& Reiner 2002, Dijkmans et al. 2010). DCLK-long and DCL contain two microtubulebinding domains, also called DCX domains (Gleeson et al. 1999, Burgess \& Reiner 2000, Vreugdenhil et al. 2007), whereas DCLK-long and DCLK-short contain a CaMK-like domain (Schenk et al. 2007). Both DCX and CaMK-like domains are not present in CARP (Vreugdenhil et al. 1999).

In vivo studies have shown that DCLKI genederived MAPs regulate neurogenesis by being involved in the mitotic spindle formation in neuroblasts (Shu et al. 2006, Vreugdenhil et al. 2007). Both loss and gain of function of the DCLK1 MAPs result in an impairment of proliferation of neuroblasts in vivo (Shu et al. 2006, Vreugdenhil et al. 2007). However, these MAPs are not only involved in the regulation of the cell cycle and determination of cell fate but also in neuronal migration and retrograde transport of glucocorticoid receptors (GR; Koizumi et al. 2006, Fitzsimons et al. 2008). The stabilisation of the microtubules by DCLK1 MAPs seems similar to the stabilisation provided by the highly homologous DCX (Shu et al. 2006).

Recently, we showed that DCL and DCLK-long are highly expressed in human NBs and gliomas (Verissimo et al. 2010). DCX is also expressed in NBs, being considered as diagnostic marker to detect minimal residual disease in NB patients (Oltra et al. 2005). We demonstrated that DCL and DCLK-long are essential for the proliferation and survival of NB cells (Verissimo et al. 2010). Moreover, the knockdown of these proteins induced apoptosis in mouse and human NB cells (Verissimo et al. 2010). Figure 2 schematically shows the consequences of silencing of DCLK1 MAPs. Gene expression profiling of NB cells after DCL and DCLK-long knockdown showed that several pathways related to the cell cycle and apoptosis were affected. Oxidative phosphorylation and oxidative stress were identified to be among the most overexpressed biological pathways and mitochondria were the most affected cell components. Hence, these studies indicate a pro-apoptotic effect of DCL/DCLKlong knockdown that may be induced by oxidative stress mechanisms that involve changes in mitochondrial activity, as reported previously (Green \& Reed 1998, Nazarewicz et al. 2007). The results also suggest that induction of apoptosis might be related to the level of disruption of mitotic spindles, which would be in agreement with the observations obtained by inhibiting proteins that stabilise mitotic spindles, such as AURKA. As explained above, AURKA inhibition leads to mitotic spindle defects and apoptosis (Hirota et al. 2003). Several studies have shown that silencing or overexpression of MAPs of the DCX family results in inhibition of cell proliferation by mitotic spindle disruption (Santra et al. 2006, 2009, Shu et al. 2006, Vreugdenhil et al. 2007). Indeed, the fact that BIRC5 is down-regulated in NB cells with DCL and DCLK-long knockdown gives indication of mitotic spindle catastrophe (Bhalla 2003, Verissimo et al. 2010). Moreover, the pro-apoptotic gene Bax was detected to be up-regulated (Verissimo et al. 2010) and has been shown to be involved in induction of apoptosis, possibly resulting from disruption of mitotic spindles and mitotic arrest (Bhalla 2003). An alternative explanation for the induction of apoptosis is the disruption of the intracellular transport of signalling proteins due to the silencing of DCL and DCLK-long. As demonstrated previously, DCL plays a crucial role in regulating retrograde translocation of signalling proteins like the GR in neuronal progenitor cells (Fitzsimons et al. 2008).

Another interesting finding was a significant correlation between DCL expression and the 


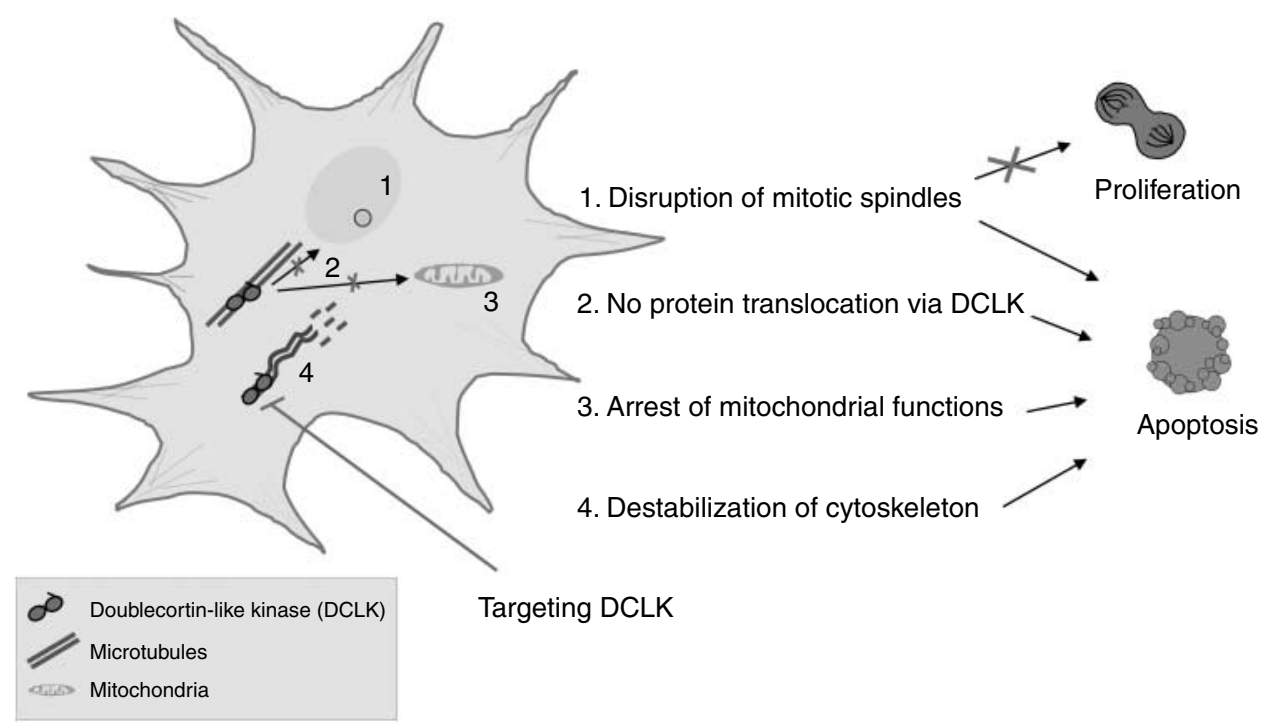

Figure 2 Representation of the consequences of targeting DCLK1-derived MAPs (DCLK). This figure is based on the results shown in Shu et al. (2006), Vreugdenhil et al. (2007), Fitzsimons et al. (2008) and Verissimo et al. (2010). Full colour version of this figure available via http://dx.doi.org/10.1530/ERC-11-0251.

expression of genes related to mitochondrial activity in human NBs. Therefore, the connection between MAP derived from the DCLKI gene and mitochondria deserves further study. One possibility is that this connection is related to the fact that mitochondria are transported along microtubules (Morris \& Hollenbeck 1995).

In summary, DCLK1-derived MAPs are highly expressed in neuroblasts and perform crucial functions related to neuroblast proliferation, migration and differentiation (Shu et al. 2006, Vreugdenhil et al. 2007). These proteins showed to be highly expressed in human NBs and their silencing induces profound apoptosis of NB cells (Verissimo et al. 2010). The apoptotic process seems to be dependent on mitochondria and may result from disruption of the mitotic spindles and arrest of the cells at prometaphase (Shu et al. 2006, Vreugdenhil et al. 2007). Therefore, we propose $D C L K 1$ as a potential molecular target for NB treatment with the promises of high specificity and low toxicity.

\section{Targeting angiogenesis: NPY and its NY2R}

High-risk NB tumours present an increased angiogenesis with high vascular index and are correlated with poor prognosis (Shusterman \& Maris 2005). This finding indicates a relation between the active angiogenesis and the growth of aggressive tumours. Hence, the inhibition of angiogenesis may represent a therapeutic approach or a powerful adjunct to other therapies for NB. The pro-angiogenic phenotype is promoted by growth factors such as VEGF and methionine aminopeptidase 2 (Shusterman \& Maris 2005, Modak \& Cheung 2010).

NPY has also been shown to stimulate angiogenesis and NB proliferation (Cohen et al. 1990). NPY is a sympathetic neurotransmitter, which acts through G-protein-coupled receptors (Y1-Y5; Lu et al. 2010). NPY is a growth factor for various cells including endothelial cells and neuronal precursors (Movafagh et al. 2006, Lu et al. 2010). NBs produce and release NPY neurotransmitter. Hence, NB patients present high levels of NPY in their plasma. These high NPY levels correlate with MYCN amplification and poor clinical outcome (Dötsch et al. 1998). NPY induces NB tumour growth and angiogenesis (Kitlinska et al. 2005). NY2R is the most common NPY receptor expressed in NB cells and blocking the binding of NPY to NY2R has been proposed as an approach to inhibit $\mathrm{NB}$ growth ( $\mathrm{Lu}$ et al. 2010). It has been shown that blocking NY2R results in a decrease in NB proliferation rate, it induces apoptosis and in vivo studies show an impairment of the tumour vascularisation as well (Lu et al. 2010). Therefore, there are strong indications that targeting angiogenesis is a promising approach, being NPY, NY2R and/or other proteins involved in this tumorigenic process (Table 2) targets to consider for NB therapy.

\section{Targeting NB invasion and metastasis: cathepsin L}

Invasion and migration of NB cells may lead to metastasis, which is the major cause of death in NB 
patients. Thus, inhibition of the invasive potential of NB cells could have major positive impact on the clinical outcome of patients that present metastatic disease.

Loss of cell adhesion and digestion of the extracellular matrix are processes that allow the invasion and migration of cancer cells (Cairns et al. 2003, Gocheva et al. 2006). Cathepsin L seems to be involved in these processes (Lankelma et al. 2010). Indeed, the active isoforms of cathepsin $\mathrm{L}$ can be found, not only intracellularly (liposomes, cytoplasm and nucleus) but also in the extracellular matrix (Zheng et al. 2009). Owing to an increase in anaerobic glycolysis, the tumour cells are in an acidic environment (Lankelma et al. 2010). In these acidic conditions, cathepsin $\mathrm{L}$ is active and digests components of the extracellular matrix, such as collagen types I and IV (Skrzydlewska et al. 2005). This indicates that inhibition of cathepsin $\mathrm{L}$ might lead to a reduction of the degradation of the extracellular matrix and, consequently, to reduction of invasion and migration of the cancer cells through the basal lamina (Lankelma et al. 2010).

Moreover, the inhibition of cathepsin L might contribute to a better action of the chemotherapeutic agents and, therefore, reduce the need for these toxic compounds. This is due to the fact that cathepsin $\mathrm{L}$ is involved in the sequestration of therapeutic drugs (Zheng et al. 2004). It has been shown that a combination of doxorubicin and cathepsin $\mathrm{L}$ inhibition is able to induce senescence in NB cells (Zheng et al. 2004). Doxorubicin is a chemotherapeutic drug used to treat cancer, such as NB. It intercalates the DNA of the cells, blocking proliferation and inducing apoptosis (Zheng et al. 2004). In vitro and in vivo studies have shown that the inhibition of cathepsin L not only reversed but also prevents the development of drug resistance (Zheng et al. 2009). It has been suggested that the inhibition of cathepsin L allows the stabilisation and increase in availability of the drug target (Zheng et al. 2009).

Altogether, there are substantial indications that cathepsin L plays a key role in the metastasis process and in the development of drug resistance. Therefore, cathepsin $\mathrm{L}$ is a promising molecular target for NB therapy.

\section{miRNAs as targets for NB therapy}

miRNAs are non-coding RNAs that repress translation and promote mRNA degradation by sequence-specific interaction with mRNA. Hence, miRNAs are important modulators of gene expression and are involved in homeostatic processes such as development, differentiation, proliferation and apoptosis (LynamLennon et al. 2009, Wu 2010). Because of these properties, it has been proposed that some miRNAs may be involved in tumour initiation and progression, functioning as oncogenes or tumour suppressors (Zhang et al. 2007a,b). Therefore, modulation of miRNAs for potential cancer therapy is of great promise (Calin \& Croce 2007, Wang \& Wu 2009, $\mathrm{Wu}$ 2011). For tumour suppressor miRNAs, restoring suppressor miRNAs by forcing their expression may be a strategy (Li et al. 2009). miRNAs with oncogene capabilities can be effectively targeted by oligonucleotides that are complementary to them, termed anti-miRNA oligonucleotides (AMOs), antagomirs or anti-miRs (Calin \& Croce 2007, Stenvang et al. 2008). Antagomirs or AMOs are 2-O-methyl oligoribonucleotides and anti-miRs are locked nucleic acid (LNA) nucleotides containing oligodeoxyribonucleotides (Dalmay 2008). For example, Stenvang et al. (2008) have shown in vitro and in vivo that LNA-anti-miR allows sequence-specific inhibition of miRNAs function. The hybridisation of LNA-modified oligonucleotides with their target RNA results in high thermal stability. In addition, they show good aqueous solubility, good transfection efficiency and low toxicity, and LNA-anti-miR compounds are in clinical trials for cancer therapy (Stenvang et al. 2008).

Despite the advances in the development of miRNAmediated therapy, some challenges still remain $(\mathrm{Li}$ et al. 2009). The first one is to sustain target specificity, which is particularly challenging because silencing only requires partial complementary between miRNA and mRNA. A second challenge is to achieve high therapeutic efficiency. Hence, the promising miRNAmediated therapy needs further investigation to improve the target selection, the molecule design and the delivery approach (Li et al. 2009).

The expression levels of miRNAs and their role in proliferation, differentiation and apoptosis have also been studied in NB (Table 3). There are indications that miRNA expression levels are predictive of clinical outcome. This suggests that miRNAs might be used as diagnostic markers and targets for NB therapy (Bray et al. 2009). An overview of differently expressed miRNAs that have been proposed as NB therapeutic targets is provided in Table 3 and their expression in other tumours is given in Supplementary Table 2, see section on supplementary data given at the end of this article.

Results show that the widespread deregulation of miRNAs expression in NB tumours is due to the chromosomal imbalances and overexpression of the MYCN (Bray et al. 2009). MYCN might regulate 
the expression of miRNAs that play a role in NB proliferation (Chen \& Stallings 2007). For example, it has been demonstrated that the $M Y C N$ oncogene in high-risk NB induces the expression of the miR-17-92 cluster (Schulte et al. 2008). This cluster consists of six individual miRNAs (miR-17, miR-18a, miR-19a, miR-19b, miR-20a and miR-92a) from a polycistronic transcript on human chromosome 13 (van Haaften \& Agami 2010). mRNAs that are targeted by miRNAs derived from the miR-17-92 cluster have key roles in cell cycle control and cell death. In particular, miR-17 and miR-20a target the CDK inhibitor CDKN1A (p21), a negative regulator of the G1-S transition and miR-17 targets the pro-apoptotic BCL2L11 (Bim) (Fontana et al. 2008). Recently, it was also found that miR-17-92 targets several effectors of transforming growth factor beta (TGF $\beta$ ) signalling cascade in NB cells (Mestdagh et al. 2010). Therefore, the miR-17-92 cluster is of particular interest as target for NB therapy.

MiR-34a may be one of the miRNAs regulated by MYCN as well. In fact, MYCN and also the antiapoptotic BCL2 have been identified as miR-34a targets (Cole et al. 2008, Wei et al. 2008). A number of other targets for miR-34a, including BIRC3, and decoy receptor 3 , are related to regulation of cell cycle progression, apoptosis, DNA repair and angiogenesis (Chang et al. 2007). MiR-34a has tumour suppressor functions and is expressed at low levels in not favourable NB tumours (Welch et al. 2007, Cole et al. 2008). In addition, low expression levels of miR34a have been associated with NB resistance towards p53-activating chemotherapeutic agents. There are indications that miR34a is transactivated by p53 (Chang et al. 2007, Hermeking 2010).

An miRNA that is highly expressed in MYCNamplified NB is MiR-380-5p. It modulates p53 expression, controlling the proliferation of NB cells and is associated with poor therapeutic outcome (Swarbrick et al. 2010). The overexpression of MiR-380-5p leads to the formation of NB tumours in mice and the inhibition of this miRNA induces apoptosis via 553 (Swarbrick et al. 2010). In vivo delivery of a miR-380-5p antagonist by i.p. injection of modified anti-sense oligonucleotides resulted in a reduction of tumour size in an NB orthotopic mouse model (Swarbrick et al. 2010). Other miRNAs suggested as targets for NB therapy are indicated in Table 3.

Clearly, expression of specific miRNAs is of critical importance for different tumorigenic processes in NB, such as tumour proliferation and metastasis. Therefore, miRNAs are certainly valuable diagnostic markers for $\mathrm{NB}$ and the development of novel therapeutic approaches based on NB-associated miRNAs is of great promise.

\section{Future prospects}

Targeting specific molecules represents a promising therapeutic approach for cancer, including NB (Segerstrom et al. 2006, Petrelli \& Giordano 2008, George et al. 2010). In contrast to conventional chemotherapy, targeted drugs give the possibility to specifically hit subpopulations of cells, thereby reducing the toxic effects (Petrelli \& Giordano 2008). Therefore, the high-affinity/high-specificity compounds have been of high interest (Schrattenholz et al. 2010). However, despite the initial enthusiasm for the efficacy of these treatments, some disappointing results have been obtained (Modak \& Cheung 2010). Patients have been confronted with relapse and developed drug resistance, which might be due to the activation of alternative pathways (Petrelli \& Giordano 2008, Modak \& Cheung 2010).

At the moment, there is a general agreement that multi-target approaches could be more effective than single-target agents (Espinoza-Fonseca 2006, Petrelli \& Giordano 2008). Some models indeed indicate that partial inhibition of a few targets is more effective than full inhibition of a single target (Csermely et al. 2005). Targeting NB cells and tumours as a system instead of targeting single molecules might allow the discovery of a novel class of multi-target drugs, which would have fewer adverse effects and less toxicity. This 'systemic' drug approach represents a new challenge in the coming decade but is of great promise (EspinozaFonseca 2006, Schrattenholz \& Soskić 2008).

Novel drugs or small molecules directed at specific targets or pathways will certainly be identified. Nevertheless, as explained above, a combination of a reduced number of these novel agents could be more effective in NB therapy than single-target approaches. A combination of low doses of agents already on the market and novel single-target agents that target, for example, ALK or DCLK1-derived MAPs is definitely a multi-target approach to consider. One would expect, for instance, a synergetic effect in the disruption of microtubules by targeting DCLK1derived MAPs, which are crucial for microtubule stabilisation, in combination with microtubuledisrupting agents, such as vinca alkaloids. Of consideration is also targeting the different processes involved in NB origin and maintenance by multitargeting proteins and/or miRNAs that play a role in those processes.

In summary, in the next 5-10 years, we predict that research in the NB therapy field will focus not only on the individual promising molecular targets but also on the different multi-target approaches. 
Particular emphasis on the understanding of the interaction between NB, its micro-environment and pharmacogenomics will be crucial. Furthermore, selection of patients that are likely to respond to the treatment will be a challenge to overcome as well. Molecular analysis of patient-specific tumours at the diagnostic might allow a precise prognosis and determination of the most effective treatment.

\section{Concluding remarks}

A new and better therapy for NB is needed, particularly for high-risk NB. Many molecular targets have been proposed in recent years but most of them have not yet been investigated in the clinic. Thus, the key for more effective therapeutic strategies might be in the novel and unexplored targets. Here, we have reviewed the existing literature on some of the targets that are under investigation in the clinic and on the proposed targets that are not yet explored in the clinic. These targets play crucial roles in the transformation of progenitor cells into NB and in the processes involved in NB progression, such as proliferation, survival, angiogenesis, invasion, migration and metastasis. Some of these not yet developed targets are undoubtedly of main interest for further investigation. We have discussed some of the targets that are not yet under investigation in the clinic in more detail. For example, we have shown that the microtubule-binding protein DCLK1 is a promising target due to its crucial role in NB proliferation and cell survival. DCLK1-derived MAPs are overexpressed in NB cells compared to normal tissues and other tumour types. miRNAs have been shown to be involved in NB tumorigenic processes and therefore proposed as therapeutic targets as well. There are several ongoing projects for modulating miRNAs expression in NBs.

Aiming at just one target involved in one of the processes of NB origin and progression has been shown to result in the activation of alternative and compensatory pathways, leading in some cases to drug resistance. Therefore, future success including reduction of long-term toxic effects may depend on rational studies of novel molecular patient-specific multi-target approaches.

\section{Supplementary data}

This is linked to the online version of the paper at http://dx. doi.org/10.1530/ERC-11-0251.

\section{Declaration of interest}

The authors declare that there is no conflict of interest that could be perceived as prejudicing the impartiality of the review reported.

\section{Funding}

This study was supported by the Dutch Top Institute Pharma.

\section{References}

Alam G, Cui H, Shi H, Yang L, Ding J, Mao L, Maltese WA \& Ding H-F 2009 MYCN promotes the expansion of Phox2B-positive neuronal progenitors to drive neuroblastoma development. American Journal of Pathology 175 856-866. (doi:10.2353/ajpath.2009.090019)

Ardini E, Magnaghi P, Orsini P, Galvani A \& Menichincheri M 2010 Anaplastic lymphoma kinase: role in specific tumours, and development of small molecule inhibitors for cancer therapy. Cancer Letters 299 81-94. (doi:10. 1016/j.canlet.2010.09.001)

Bahr C \& Groner B 2005 The IGF-1 receptor and its contributions to metastatic tumor growth-novel approaches to the inhibition of IGF-1R function. Growth Factors 23 1-14. (doi:10.1080/08977190400020229)

Balamuth NJ, Wood A, Wang Q, Jagannathan J, Mayes P, Zhang Z, Chen Z, Rappaport E, Courtright J, Pawel B et al. 2010 Serial transcriptome analysis and crossspecies integration identifies centromere-associated protein $\mathrm{E}$ as a novel neuroblastoma target. Cancer Research 70 2749-2758. (doi:10.1158/0008-5472.CAN09-3844)

Barth BM, Gustafson SJ, Young MM, Shanmugavelandy SS, Kaiser JM, Cabot MC, Kester M \& Kuhn TB 2010 Inhibition of NADPH oxidase by glucosylceramide confers chemoresistance. Cancer Biology \& Therapy 10 1126-1136. (doi:10.4161/cbt.10.11.13438)

Beierle EA, Ma X, Stewart J, Nyberg C, Trujillo A, Cance WG \& Golubovskaya VM 2010 Inhibition of focal adhesion kinase decreases tumor growth in human neuroblastoma. Cell Cycle 9 1005-1015. (doi:10.4161/cc. 9.5.10936)

Bhalla KN 2003 Microtubule-targeted anticancer agents and apoptosis. Oncogene 22 9075-9086. (doi:10.1038/sj.onc. 1207233)

Bray I, Bryan K, Prenter S, Buckley PG, Foley NH, Murphy DM, Alcock L, Mestdagh P, Vandesompele J, Speleman F et al. 2009 Widespread dysregulation of miRNAs by MYCN amplification and chromosomal imbalances in neuroblastoma: association of miRNA expression with survival. PLOS ONE 4 e7850. (doi:10.1371/journal.pone. 0007850)

Brignole C, Marimpietri D, Di Paolo D, Perri P, Morandi F, Pastorino F, Zorzoli A, Pagnan G, Loi M, Caffa I et al. 2010 Therapeutic targeting of TLR9 inhibits cell growth and induces apoptosis in neuroblastoma. Cancer Research 70 9816-9826. (doi:10.1158/0008-5472.CAN-10-1251) 
Brodeur GM, Seeger RC, Schwab M, Varmus HE \& Bishop JM 1984 Amplification of N-myc in untreated human neuroblastomas correlates with advanced disease stage. Science 224 1121-1124. (doi:10.1126/science.6719137)

Brodeur GM, Pritchard J, Berthold F, Carlsen NL, Castel V, Castelberry RP, De Bernardi B, Evans AE, Favrot M \& Hedborg F 1993 Revisions of the international criteria for neuroblastoma diagnosis, staging, and response to treatment. Journal of Clinical Oncology: Official Journal of the American Society of Clinical Oncology 11 1466-1477.

Burgess HA \& Reiner O 2000 Doublecortin-like kinase is associated with microtubules in neuronal growth cones. Molecular and Cellular Neurosciences 16 529-541. (doi:10.1006/mcne.2000.0891)

Burgess HA \& Reiner O 2002 Alternative splice variants of doublecortin-like kinase are differentially expressed and have different kinase activities. Journal of Biological Chemistry 277 17696-17705. (doi:10.1074/jbc. M111981200)

Cairns RA, Khokha R \& Hill RP 2003 Molecular mechanisms of tumor invasion and metastasis: an integrated view. Current Molecular Medicine 3 659-671. (doi:10.2174/1566524033479447)

Calin GA \& Croce CM 2007 Chromosomal rearrangements and microRNAs: a new cancer link with clinical implications. Journal of Clinical Investigation 117 2059-2066. (doi:10.1172/JCI32577)

Carol H, Boehm I, Reynolds CP, Kang MH, Maris JM, Morton CL, Gorlick R, Kolb EA, Keir ST \& Wu J 2011 Efficacy and pharmacokinetic/pharmacodynamic evaluation of the Aurora kinase A inhibitor MLN8237 against preclinical models of pediatric cancer. Cancer Chemotherapy and Pharmacology [in press]. (doi:10. 1007/s00280-011-1618-8)

Castel V, Segura V \& Cañete A 2010 Treatment of high-risk neuroblastoma with anti-GD2 antibodies. Clinical and Translational Oncology 12 788-793. (doi:10.1007/ s12094-010-0600-y)

Chamdin A, Jarzembowski JA, Subramanian C, Kuick R, Lee JS-J, Kwok RP, Castle VP \& Opipari AW 2009 Bcl6 is expressed in neuroblastoma: tumor cell type-specific expression predicts outcome. Translational Oncology 2 128-137. (doi:10.1593/tlo.08220)

Chang T-C, Wentzel EA, Kent OA, Ramachandran K, Mullendore M, Lee KH, Feldmann G, Yamakuchi M, Ferlito M, Lowenstein CJ et al. 2007 Transactivation of miR-34a by p53 broadly influences gene expression and promotes apoptosis. Molecular Cell 26 745-752. (doi:10. 1016/j.molcel.2007.05.010)

Chen Y \& Stallings RL 2007 Differential patterns of microRNA expression in neuroblastoma are correlated with prognosis, differentiation, and apoptosis. Cancer Research 67 976-983. (doi:10.1158/0008-5472.CAN06-3667)

Cimmino F, Schulte JH, Zollo M, Koster J, Versteeg R, Iolascon A, Eggert A \& Schramm A 2009 Galectin-1 is a major effector of TrkB-mediated neuroblastoma aggressiveness. Oncogene 28 2015-2023. (doi:10.1038/onc. 2009.70)

Coffey DC, Kutko MC, Glick RD, Butler LM, Heller G, Rifkind RA, Marks PA, Richon VM \& La Quaglia MP 2001 The histone deacetylase inhibitor, CBHA, inhibits growth of human neuroblastoma xenografts in vivo, alone and synergistically with all-trans retinoic acid. Cancer Research 61 3591-3594.

Cohen PS, Cooper MJ, Helman LJ, Thiele CJ, Seeger RC \& Israel MA 1990 Neuropeptide Y expression in the developing adrenal gland and in childhood neuroblastoma tumors. Cancer Research 50 6055-6061.

Cole KA, Attiyeh EF, Mosse YP, Laquaglia MJ, Diskin SJ, Brodeur GM \& Maris JMA 2008 A functional screen identifies miR-34a as a candidate neuroblastoma tumor suppressor gene. Molecular Cancer Research 6 735-742. (doi:10.1158/1541-7786.MCR-07-2102)

Colella R, Lu G, Glazewski L, Korant B, Matlapudi A, England MR, Craft C, Frantz CN \& Mason RW 2010 Induction of cell death in neuroblastoma by inhibition of cathepsins B and L. Cancer Letters 294 195-203. (doi:10.1016/j.canlet.2010.01.037)

Contardi E, Palmisano GL, Tazzari PL, Martelli AM, Fala F, Fabbi M, Kato T, Lucarelli E, Donati D, Polito L et al. 2005 CTLA-4 is constitutively expressed on tumor cells and can trigger apoptosis upon ligand interaction. International Journal of Cancer 117 538-550. (doi:10.1002/ijc.21155)

Coquelle FM, Levy T, Bergmann S, Wolf SG, Bar-El D, Sapir T, Brody Y, Orr I, Barkai N, Eichele G et al. 2006 Common and divergent roles for members of the mouse DCX superfamily. Cell Cycle 5 976-983. (doi:10.4161/ cc.5.9.2715)

Coulter DW, Blatt J, D'Ercole AJ \& Moats-Staats BM 2008 IGF-I receptor inhibition combined with rapamycin or temsirolimus inhibits neuroblastoma cell growth. Anticancer Research 28 1509-1516.

Csermely P, Agoston V \& Pongor S 2005 The efficiency of multi-target drugs: the network approach might help drug design. Trends in Pharmacological Sciences 26 178-182. (doi:10.1016/j.tips.2005.02.007)

Dalmay T 2008 Identification of genes targeted by microRNAs. Biochemical Society Transactions 36 1194-1196. (doi:10.1042/BST0361194)

Dole M, Nunez G, Merchant AK, Maybaum J, Rode CK, Bloch CA \& Castle VP 1994 Bcl-2 inhibits chemotherapy-induced apoptosis in neuroblastoma. Cancer Research 54 3253-3259.

Dötsch J, Christiansen H, Hänze J, Lampert F \& Rascher W 1998 Plasma neuropeptide Y of children with neuroblastoma in relation to stage, age and prognosis, and tissue neuropeptide Y. Regulatory Peptides 75-76 185-190. (doi:10.1016/S0167-0115(98)00067-6)

Dickey A, Schleicher S, Leahy K, Hu R, Hallahan D \& Thotala DK 2011 GSK-3 $\beta$ inhibition promotes cell death, 
apoptosis, and in vivo tumor growth delay in neuroblastoma neuro-2A cell line. Journal of Neuro-Oncology 104 145-153. (doi:10.1007/s11060-010-0491-3)

Dijkmans TF, van Hooijdonk LWA, Fitzsimons CP \& Vreugdenhil E 2010 The doublecortin gene family and disorders of neuronal structure. Central Nervous System Agents in Medicinal Chemistry 10 32-46.

Duffy MJ, O’Donovan N, Brennan DJ, Gallagher WM \& Ryan BM 2007 Survivin: a promising tumor biomarker. Cancer Letters 249 49-60. (doi:10.1016/j.canlet.2006. 12.020)

El-Badry OM, Romanus JA, Helman LJ, Cooper MJ, Rechler MM \& Israel MA 1989 Autonomous growth of a human neuroblastoma cell line is mediated by insulin-like growth factor II. Journal of Clinical Investigation 84 829-839. (doi:10.1172/JCI114243)

Espinoza-Fonseca LM 2006 The benefits of the multi-target approach in drug design and discovery. Bioorganic \& Medicinal Chemistry 14 896-897. (doi:10.1016/j.bmc. 2005.09.011)

Evans AE, Kisselbach KD, Yamashiro DJ, Ikegaki N, Camoratto AM, Dionne CA \& Brodeur GM 1999 Antitumor activity of CEP-751 (KT-6587) on human neuroblastoma and medulloblastoma xenografts. Clinical Cancer Research 5 3594-3602.

Evans AE, Kisselbach KD, Liu X, Eggert A, Ikegaki N, Camoratto AM, Dionne C \& Brodeur GM 2001 Effect of CEP-751 (KT-6587) on neuroblastoma xenografts expressing TrkB. Medical and Pediatric Oncology 36 181-184. (doi:10.1002/1096-911X(20010101)36:1< $181::$ AID-MPO1043>3.0.CO;2-Q)

Fitzsimons CP, Ahmed S, Wittevrongel CFW, Schouten TG, Dijkmans TF, Scheenen WJJM, Schaaf MJM, de Kloet ER \& Vreugdenhil E 2008 The microtubule-associated protein doublecortin-like regulates the transport of the glucocorticoid receptor in neuronal progenitor cells. Molecular Endocrinology 22 248-262. (doi:10.1210/me. 2007-0233)

Foley NH, Bray IM, Tivnan A, Bryan K, Murphy DM, Buckley PG, Ryan J, O’Meara A, O’Sullivan M \& Stallings RL 2010 microRNA-184 inhibits neuroblastoma cell survival through targeting the serine/threonine kinase AKT2. Molecular Cancer 9 83. (doi:10.1186/1476-4598-9-83)

Fong A \& Park JR 2009 High-risk neuroblastoma: a therapy in evolution. Pediatric Hematology and Oncology 26 539-548. (doi:10.3109/08880010903121173)

Fontana L, Fiori ME, Albini S, Cifaldi L, Giovinazzi S, Forloni M, Boldrini R, Donfrancesco A, Federici V, Giacomini P et al. 2008 Antagomir-17-5p abolishes the growth of therapy-resistant neuroblastoma through $\mathrm{p} 21$ and BIM. PLOS ONE 3 e2236. (doi:10.1371/journal.pone. 0002236)

Fulda S 2009 The PI3K/Akt/mTOR pathway as therapeutic target in neuroblastoma. Current Cancer Drug Targets 9 729-737. (doi:10.2174/156800909789271521)

Furchert SE, Lanvers-Kaminsky C, Juurgens H, Jung M, Loidl A \& Fruhwald MC 2007 Inhibitors of histone deacetylases as potential therapeutic tools for high-risk embryonal tumors of the nervous system of childhood. International Journal of Cancer 120 1787-1794. (doi:10. 1002/ijc.22401)

Furman WL, McGregor LM, McCarville MB, Onciu M, Davidoff AM, Kovach S, Hawkins D, McPherson V, Houghton PJ, Billups CA et al. 2011 A single-arm pilot phase II study of gefitinib and irinotecan in children with newly diagnosed high-risk neuroblastoma. Investigational New Drugs [in press]. (doi:10.1007/s10637-011-9724-3)

Geerts D, Wallick CJ, Koomoa D-LT, Koster J, Versteeg R, Go RCV \& Bachmann AS 2007 Expression of prenylated Rab acceptor 1 domain family, member 2 (PRAF2) in neuroblastoma: correlation with clinical features, cellular localization, and cerulenin-mediated apoptosis regulation. Clinical Cancer Research: an Official Journal of the American Association for Cancer Research 13 6312-6319. (doi:10.1158/1078-0432.CCR-07-0829)

Geoerger B, Brasme JF, Daudigeos-Dubus E, Opolon P, Venot C, Debussche L, Vrignaud P \& Vassal G 2010 Anti-insulin-like growth factor 1 receptor antibody EM164 (murine AVE1642) exhibits anti-tumour activity alone and in combination with temozolomide against neuroblastoma. European Journal of Cancer 46 3251-3262. (doi:10.1016/j.ejca.2010.06.005)

George RE, Sanda T, Hanna M, Frohling S, Luther W II, Zhang J, Ahn Y, Zhou W, London WB, McGrady P et al. 2008 Activating mutations in ALK provide a therapeutic target in neuroblastoma. Nature 455 975-978. (doi:10. 1038/nature07397)

George RE, Diller L \& Bernstein ML 2010 Pharmacotherapy of neuroblastoma. Expert Opinion on Pharmacotherapy 11 1467-1478. (doi:10.1517/14656566.2010.482100)

Gershon TR, Oppenheimer O, Chin SS \& Gerald WL 2005 Temporally regulated neural crest transcription factors distinguish neuroectodermal tumors of varying malignancy and differentiation. Neoplasia 7 575-584. (doi:10. 1593/neo.04637)

Gleeson JG, Lin PT, Flanagan LA \& Walsh CA 1999 Doublecortin is a microtubule-associated protein and is expressed widely by migrating neurons. Neuron $\mathbf{2 3}$ 257-271. (doi:10.1016/S0896-6273(00)80778-3)

Glynn RW, Miller N, Whelan MC \& Kerin MJ 2010 Topoisomerase 2 alpha and the case for individualized breast cancer therapy. Annals of Surgical Oncology 17 1392-1397. (doi:10.1245/s10434-009-0855-0)

Gocheva V, Zeng W, Ke D, Klimstra D, Reinheckel T, Peters C, Hanahan D \& Joyce JA 2006 Distinct roles for cysteine cathepsin genes in multistage tumorigenesis. Genes and Development 20 543-556. (doi:10.1101/gad. 1407406)

Green DR \& Reed JC 1998 Mitochondria and apoptosis. Science 281 1309-1312. (doi:10.1126/science.281.5381. 1309)

van Haaften G \& Agami R 2010 Tumorigenicity of the miR-17-92 cluster distilled. Genes and Development $\mathbf{2 4}$ 1-4. (doi:10.1101/gad.1887110) 
Haase GM, Perez C \& Atkinson JB 1999 Current aspects of biology, risk assessment, and treatment of neuroblastoma. Seminars in Surgical Oncology 16 91-104. (doi:10.1002/ (SICI)1098-2388(199903)16:2<91::AID-SSU3>3.0. $\mathrm{CO} ; 2-1)$

Hallbook F, Bäckström A, Kullander K, Kylberg A, Williams R \& Ebendal T 1995 Neurotrophins and their receptors in chicken neuronal development. International Journal of Developmental Biology 39 855-868.

Harel L, Costa B \& Fainzilber M 2010 On the death Trk. Developmental Neurobiology 70 298-303. (doi:10.1002/ dneu.20769)

Hermeking H 2010 The miR-34 family in cancer and apoptosis. Cell Death and Differentiation 17 193-199. (doi:10.1038/cdd.2009.56)

Hirota T, Kunitoku N, Sasayama T, Marumoto T, Zhang D, Nitta M, Hatakeyama K \& Saya H 2003 Aurora-A and an interacting activator, the LIM protein Ajuba, are required for mitotic commitment in human cells. Cell 114 585-598. (doi:10.1016/S0092-8674(03)00642-1)

Ho R, Eggert A, Hishiki T, Minturn JE, Ikegaki N, Foster P, Camoratto AM, Evans AE \& Brodeur GM 2002 Resistance to chemotherapy mediated by TrkB in neuroblastomas. Cancer Research 62 6462-6466.

Hu K, Lee C, Qiu D, Fotovati A, Davies A, Abu-Ali S, Wai D, Lawlor ER, Triche TJ, Pallen CJ et al. 2009 Small interfering RNA library screen of human kinases and phosphatases identifies polo-like kinase 1 as a promising new target for the treatment of pediatric rhabdomyosarcomas. Molecular Cancer Therapeutics 8 3024-3035. (doi:10.1158/1535-7163.MCT-09-0365)

Huber K 2006 The sympathoadrenal cell lineage: specification, diversification, and new perspectives. Developmental Biology 298 335-343. (doi:10.1016/j.ydbio.2006. 07.010)

Islam A, Kageyama H, Hashizume K, Kaneko Y \& Nakagawara A 2000a Role of survivin, whose gene is mapped to $17 \mathrm{q} 25$, in human neuroblastoma and identification of a novel dominant-negative isoform, survivinbeta/2B. Medical and Pediatric Oncology 35 550-553. (doi:10.1002/1096-911X(20001201)35:6<550::AID$\mathrm{MPO} 12>3.0 . \mathrm{CO} ; 2-\mathrm{Y})$

Islam A, Kageyama H, Takada N, Kawamoto T, Takayasu H, Isogai E, Ohira M, Hashizume K, Kobayashi H, Kaneko Y et al. $2000 \mathrm{~b}$ High expression of Survivin, mapped to $17 q 25$, is significantly associated with poor prognostic factors and promotes cell survival in human neuroblastoma. Oncogene 19 617-623. (doi:10.1038/sj.onc. 1203358)

Itoh Y, Ishikawa M, Naito M \& Hashimoto Y 2010 Protein knockdown using methyl bestatin-ligand hybrid molecules: design and synthesis of inducers of ubiquitination-mediated degradation of cellular retinoic acid-binding proteins. Journal of the American Chemical Society 132 5820-5826. (doi:10.1021/ ja100691p)
Johnson E, Dean SM \& Sondel PM 2007 Antibody-based immunotherapy in high-risk neuroblastoma. Expert Reviews in Molecular Medicine 9 1-21. (doi:10.1017/ S1462399407000518)

Kaneko M, Kaneko S \& Suzuki K 2009 Prolonged low-dose administration of the cyclooxygenase- 2 inhibitor celecoxib enhances the antitumor activity of irinotecan against neuroblastoma xenografts. Cancer Science 100 2193-2201. (doi:10.1111/j.1349-7006.2009.01280.x)

Kang J, Kamal A, Burrows FJ, Evers BM \& Chung DH 2006 Inhibition of neuroblastoma xenograft growth by Hsp90 inhibitors. Anticancer Research 26 1903-1908.

Kang J, Rychahou PG, Ishola TA, Mourot JM, Evers BM \& Chung DH $2008 \mathrm{~N}$-myc is a novel regulator of PI3Kmediated VEGF expression in neuroblastoma. Oncogene 27 3999-4007. (doi:10.1038/onc.2008.15)

Khew-Goodall Y \& Goodall GJ 2010 Myc-modulated miR-9 makes more metastases. Nature Cell Biology 12 209-211. (doi:10.1038/ncb0310-209)

Kitlinska J, Abe K, Kuo L, Pons J, Yu M, Li L, Tilan J, Everhart L, Lee EW, Zukowska Z et al. 2005 Differential effects of neuropeptide $\mathrm{Y}$ on the growth and vascularization of neural crest-derived tumors. Cancer Research 65 1719-1728. (doi:10.1158/0008-5472.CAN-04-2192)

Koizumi H, Tanaka T \& Gleeson JG 2006 Doublecortin-like kinase functions with doublecortin to mediate fiber tract decussation and neuronal migration. Neuron 49 55-66. (doi:10.1016/j.neuron.2005.10.040)

Laneve P, Di Marcotullio L, Gioia U, Fiori ME, Ferretti E, Gulino A, Bozzoni I \& Caffarelli E 2007 The interplay between microRNAs and the neurotrophin receptor tropomyosin-related kinase $\mathrm{C}$ controls proliferation of human neuroblastoma cells. PNAS 104 7957-7962. (doi:10.1073/pnas.0700071104)

Lankelma JM, Voorend DM, Barwari T, Koetsveld J, Van der Spek AH, De Porto APNA, Van Rooijen G \& Van Noorden CJF 2010 Cathepsin L target in cancer treatment? Life Sciences 86 225-233. (doi:10.1016/j.lfs. 2009.11.016)

Lasorella A, Boldrini R, Dominici C, Donfrancesco A, Yokota Y, Inserra A \& Iavarone A 2002 Id 2 is critical for cellular proliferation and is the oncogenic effector of $\mathrm{N}$-myc in human neuroblastoma. Cancer Research 62 301-306.

Lazer G \& Katzav S 2011 Guanine nucleotide exchange factors for RhoGTPases: good therapeutic targets for cancer therapy? Cellular Signalling 23 969-979. (doi:10. 1016/j.cellsig.2010.10.022)

Lestini BJ, Goldsmith KC, Fluchel MN, Liu X, Chen NL, Goyal B, Pawel BR \& Hogarty MD 2009 Mcl1 downregulation sensitizes neuroblastoma to cytotoxic chemotherapy and small molecule Bcl2-family antagonists. Cancer Biology \& Therapy 8 1587-1595. (doi:10.4161/ cbt.8.16.8964)

Li C, Feng Y, Coukos G \& Zhang L 2009 Therapeutic microRNA strategies in human cancer. AAPS Journal 11 747-757. (doi:10.1208/s12248-009-9145-9) 
Li Y, Luo F, Wei L, Liu Z \& Xu P 2010 Knockdown of glycogen synthase kinase 3 beta attenuates 6-hydroxydopamine-induced apoptosis in SH-SY5Y cells. Neuroscience Letters 487 41-46. (doi:10.1016/ j.neulet.2010.09.070)

Li Z, Oh DY, Nakamura K \& Thiele CJ 2011 Perifosineinduced inhibition of akt attenuates brain-derived neurotrophic factor/TrkB-induced chemoresistance in neuroblastoma in vivo. Cancer [in press]. (doi:10.1002/cncr. 26133)

Liu X, Turbyville T, Fritz A \& Whitesell L 1998 Inhibition of insulin-like growth factor I receptor expression in neuroblastoma cells induces the regression of established tumors in mice. Cancer Research 58 5432-5438.

Look AT, Hayes FA, Shuster JJ, Douglass EC, Castleberry RP, Bowman LC, Smith EI \& Brodeur GM 1991 Clinical relevance of tumor cell ploidy and $N-m y c$ gene amplification in childhood neuroblastoma: a Pediatric Oncology Group study. Journal of Clinical Oncology: Official Journal of the American Society of Clinical Oncology 9 581-591.

LoPiccolo J, Blumenthal GM, Bernstein WB \& Dennis PA 2008 Targeting the PI3K/Akt/mTOR pathway: effective combinations and clinical considerations. Drug Resistance Updates 11 32-50. (doi:10.1016/j.drup.2007.11. 003)

Lu C, Everhart L, Tilan J, Kuo L, Sun C-CJ, Munivenkatappa RB, Jönsson-Rylander A-C, Sun J, Kuan-Celarier A, Li L et al. 2010 Neuropeptide Y and its Y2 receptor: potential targets in neuroblastoma therapy. Oncogene 29

5630-5642. (doi:10.1038/onc.2010.301)

Lynam-Lennon N, Maher SG \& Reynolds JV 2009 The roles of microRNA in cancer and apoptosis. Biological Reviews of the Cambridge Philosophical Society 84 55-71. (doi:10.1111/j.1469-185X.2008.00061.x)

Ma L, Young J, Prabhala H, Pan E, Mestdagh P, Muth D, Teruya-Feldstein J, Reinhardt F, Onder TT, Valastyan S et al. 2010 miR-9, a MYC/MYCN-activated microRNA, regulates E-cadherin and cancer metastasis. Nature Cell Biology 12 247-256. (doi:10.1038/ncb2024)

Maris JM \& Matthay KK 1999 Molecular biology of neuroblastoma. Journal of Clinical Oncology: Official Journal of the American Society of Clinical Oncology 17 2264-2279.

Maris JM, Hogarty MD, Bagatell R \& Cohn SL 2007 Neuroblastoma. Lancet 369 2106-2120. (doi:10.1016/ S0140-6736(07)60983-0)

Martin-Zanca D, Hughes SH \& Barbacid M 1986 A human oncogene formed by the fusion of truncated tropomyosin and protein tyrosine kinase sequences. Nature 319 743-748. (doi:10.1038/319743a0)

McKee AE \& Thiele CJ 2006 Targeting caspase 8 to reduce the formation of metastases in neuroblastoma. Expert Opinion on Therapeutic Targets 10 703-708. (doi:10. 1517/14728222.10.5.703)

Mestdagh P, Boström A-K, Impens F, Fredlund E, Van Peer $\mathrm{G}$, De Antonellis P, von Stedingk K, Ghesquière B,
Schulte S, Dews M et al. 2010 The miR-17-92 microRNA cluster regulates multiple components of the TGF- $\beta$ pathway in neuroblastoma. Molecular Cell 40 762-773. (doi:10.1016/j.molcel.2010.11.038)

Misawa A, Hosoi H, Arimoto A, Shikata T, Akioka S, Matsumura T, Houghton PJ \& Sawada T 2000 N-Myc induction stimulated by insulin-like growth factor I through mitogen-activated protein kinase signaling pathway in human neuroblastoma cells. Cancer Research 60 64-69.

Modak S \& Cheung N-KV 2010 Neuroblastoma: therapeutic strategies for a clinical enigma. Cancer Treatment Reviews 36 307-317. (doi:10.1016/j.ctrv.2010.02.006)

Molenaar JJ, Ebus ME, Koster J, van Sluis P, van Noesel CJM, Versteeg R \& Caron HN 2008 Cyclin D1 and CDK4 activity contribute to the undifferentiated phenotype in neuroblastoma. Cancer Research 68 2599-2609. (doi:10. 1158/0008-5472.CAN-07-5032)

Molenaar JJ, Ebus ME, Geerts D, Koster J, Lamers F, Valentijn LJ, Westerhout EM, Versteeg R \& Caron HN 2009 Inactivation of CDK2 is synthetically lethal to MYCN over-expressing cancer cells. PNAS 106 12968-12973. (doi:10.1073/pnas.0901418106)

Molenaar JJ, Ebus ME, Koster J, Santo E, Geerts D, Versteeg $\mathrm{R} \&$ Caron HN 2010 Cyclin D1 is a direct transcriptional target of GATA3 in neuroblastoma tumor cells. Oncogene 29 2739-2745. (doi:10.1038/onc.2010.21)

Moll UM \& Slade N 2004 p63 and p73: roles in development and tumor formation. Molecular Cancer Research 2 371-386.

Mora J \& Gerald WL 2004 Origin of neuroblastic tumors: clues for future therapeutics. Expert Review of Molecular Diagnostics 4 293-302. (doi:10.1586/14737159.4.3.293)

Morris RL \& Hollenbeck PJ 1995 Axonal transport of mitochondria along microtubules and F-actin in living vertebrate neurons. Journal of Cell Biology 131 1315-1326. (doi:10.1083/jcb.131.5.1315)

Morton CL, Maris JM, Keir ST, Gorlick R, Kolb EA, Billups CA, Wu J, Smith MA \& Houghton PJ 2011 Combination testing of cediranib (AZD2171) against childhood cancer models by the pediatric preclinical testing program. Pediatric Blood \& Cancer [in press]. (doi:10.1002/pbc. 23159)

Mosse YP, Laudenslager M, Longo L, Cole KA, Wood A, Attiyeh EF, Laquaglia MJ, Sennett R, Lynch JE, Perri P et al. 2008 Identification of ALK as a major familial neuroblastoma predisposition gene. Nature 455 930-935. (doi:10.1038/nature07261)

Motegi A, Fujimoto J, Kotani M, Sakuraba H \& Yamamoto T 2004 ALK receptor tyrosine kinase promotes cell growth and neurite outgrowth. Journal of Cell Science 117 3319-3329. (doi:10.1242/jcs.01183)

Movafagh S, Hobson JP, Spiegel S, Kleinman HK \& Zukowska Z 2006 Neuropeptide Y induces migration, proliferation, and tube formation of endothelial cells bimodally via Y1, Y2, and Y5 receptors. FASEB Journal 20 1924-1926. (doi:10.1096/fj.05-4770fje) 
Nakagawara A 2001 Trk receptor tyrosine kinases: a bridge between cancer and neural development. Cancer Letters 169 107-114. (doi:10.1016/S0304-3835(01)00530-4)

Nakagawara A 2004 Neural crest development and neuroblastoma: the genetic and biological link. Progress in Brain Research 146 233-242. (doi:10.1016/S00796123(03)46015-9)

Nakagawara A 2005 Molecular and developmental biology of neuroblastoma. In Neuroblastoma, edn 1, pp 41-53. Eds N-K Cheung \& SL Cohn. Heidelberg, Germany: Springer.

Nakagawara A \& Ohira M 2004 Comprehensive genomics linking between neural development and cancer: neuroblastoma as a model. Cancer Letters 204 213-224. (doi:10.1016/S0304-3835(03)00457-9)

Nakagawara A, Arima-Nakagawara M, Scavarda NJ, Azar CG, Cantor AB \& Brodeur GM 1993 Association between high levels of expression of the TRK gene and favorable outcome in human neuroblastoma. New England Journal of Medicine 328 847-854. (doi:10.1056/ NEJM199303253281205)

Nazarewicz RR, Zenebe WJ, Parihar A, Larson SK, Alidema E, Choi J \& Ghafourifar P 2007 Tamoxifen induces oxidative stress and mitochondrial apoptosis via stimulating mitochondrial nitric oxide synthase. Cancer Research 67 1282-1290. (doi:10.1158/0008-5472.CAN06-3099)

van Noesel MM \& Versteeg R 2004 Pediatric neuroblastomas: genetic and epigenetic 'danse macabre'. Gene 325 1-15. (doi:10.1016/j.gene.2003.09.042)

Ogawa S, Takita J, Sanada M \& Hayashi Y 2011 Oncogenic mutations of ALK in neuroblastoma. Cancer Science $\mathbf{1 0 2}$ 302-308. (doi:10.1111/j.1349-7006.2010.01825.x)

Oltra S, Martinez F, Orellana C, Grau E, Fernandez JM, Cañete A \& Castel V 2005 The doublecortin gene, a new molecular marker to detect minimal residual disease in neuroblastoma. Diagnostic Molecular Pathology 14 53-57. (doi:10.1097/01.pas.0000149876.32376.c0)

Opel D, Poremba C, Simon T, Debatin KM \& Fulda S 2007 Activation of Akt predicts poor outcome in neuroblastoma. Cancer Research 67 735-745. (doi:10.1158/00085472.CAN-06-2201)

Otto T, Horn S, Brockmann M, Eilers U, Schuttrumpf L, Popov N, Kenney AM, Schulte JH, Beijersbergen R, Christiansen $\mathrm{H}$ et al. 2009 Stabilization of N-Myc is a critical function of Aurora A in human neuroblastoma. Cancer Cell 15 67-78. (doi:10.1016/j.ccr.2008.12.005)

Park JR, Eggert A \& Caron H 2008 Neuroblastoma: biology, prognosis, and treatment. Pediatric Clinics of North America 55 97-120. (doi:10.1016/j.pcl.2007.10.014)

Petrelli A \& Giordano S 2008 From single- to multi-target drugs in cancer therapy: when aspecificity becomes an advantage. Current Medicinal Chemistry 15 422-432. (doi:10.2174/092986708783503212)

Pietras A, Hansford LM, Johnsson AS, Bridges E, Sjölund J, Gisselsson D, Rehn M, Beckman S, Noguera R, Navarro S et al. 2009 HIF-2alpha maintains an undifferentiated state in neural crest-like human neuroblastoma tumor-initiating cells. PNAS 106 16805-16810. (doi:10.1073/pnas. 0904606106)

Pomeroy SL, Tamayo P, Gaasenbeek M, Sturla LM, Angelo M, McLaughlin ME, Kim JYH, Goumnerova LC, Black PM, Lau C et al. 2002 Prediction of central nervous system embryonal tumour outcome based on gene expression. Nature 415 436-442. (doi:10.1038/415436a)

Qing G, Skuli N, Mayes PA, Pawel BR, Martinez D, Maris JM \& Simon MC 2010 Combinatorial regulation of neuroblastoma tumor progression by N-Myc and hypoxia inducible factor (HIF)-1 $\{$ alpha $\}$. Cancer Research 70 10351-10361. (doi:10.1158/0008-5472.CAN-10-0740)

Ragusa M, Majorana A, Banelli B, Barbagallo D, Statello L, Casciano I, Guglielmino MR, Duro LR, Scalia M, Magro G et al. 2010 MIR152, MIR200B, and MIR338, human positional and functional neuroblastoma candidates, are involved in neuroblast differentiation and apoptosis. Journal of Molecular Medicine 88 1041-1053. (doi:10. 1007/s00109-010-0643-0)

Reiner O, Coquelle FM, Peter B, Levy T, Kaplan A, Sapir T, Orr I, Barkai N, Eichele G \& Bergmann S 2006 The evolving doublecortin (DCX) superfamily. BMC Genomics 7 188. (doi:10.1186/1471-2164-7-188)

Ren Y, Chan HM, Fan J, Xie Y, Chen YX, Li W, Jiang GP, Liu Q, Meinhardt A \& Tam PKH 2006 Inhibition of tumor growth and metastasis in vitro and in vivo by targeting macrophage migration inhibitory factor in human neuroblastoma. Oncogene 25 3501-3508. (doi:10.1038/sj.onc. 1209395)

Rheingold SR, Hogarty MD, Blaney SM, Zwiebel JA, SaukSchubert C, Chandula R, Krailo MD \& Adamson PC 2007 Phase I trial of G3139, a bcl-2 antisense oligonucleotide, combined with doxorubicin and cyclophosphamide in children with relapsed solid tumors: a Children's Oncology Group Study. Journal of Clinical Oncology 25 1512-1518. (doi:10.1200/JCO.2006.09.5125)

Santra M, Zhang X, Santra S, Jiang F \& Chopp M 2006 Ectopic doublecortin gene expression suppresses the malignant phenotype in glioblastoma cells. Cancer Research 66 11726-11735. (doi:10.1158/0008-5472. CAN-06-1978)

Santra M, Santra S, Roberts C, Zhang RL \& Chopp M 2009 Doublecortin induces mitotic microtubule catastrophe and inhibits glioma cell invasion. Journal of Neurochemistry 108 231-245. (doi:10.1111/j.1471-4159.2008. 05758.x)

Sarbassov DD, Ali SM \& Sabatini DM 2005 Growing roles for the mTOR pathway. Current Opinion in Cell Biology 17 596-603. (doi:10.1016/j.ceb.2005.09.009)

Schenk GJ, Engels B, Zhang Y-P, Fitzsimons CP, Schouten T, Kruidering M, de Kloet ER \& Vreugdenhil E 2007 A potential role for calcium/calmodulin-dependent protein kinase-related peptide in neuronal apoptosis: in vivo and in vitro evidence. European Journal of Neuroscience $\mathbf{2 6}$ 3411-3420. (doi:10.1111/j.1460-9568.2007.05956.x) 
Schrattenholz A \& Soskić V 2008 What does systems biology mean for drug development? Current Medicinal Chemistry 15 1520-1528. (doi:10.2174/092986708784638843)

Schrattenholz A, Groebe K \& Soskic V 2010 Systems biology approaches and tools for analysis of interactomes and multi-target drugs. Methods in Molecular Biology 662 29-58. (doi:10.1007/978-1-60761-800-3_2)

Schulte JH, Horn S, Otto T, Samans B, Heukamp LC, Eilers U-C, Krause M, Astrahantseff K, Klein-Hitpass L, Buettner R et al. $2008 \mathrm{MYCN}$ regulates oncogenic microRNAs in neuroblastoma. International Journal of Cancer 122 699-704. (doi:10.1002/ijc.23153)

Segerstrom L, Fuchs D, Backman U, Holmquist K, Christofferson R \& Azarbayjani F 2006 The anti-VEGF antibody bevacizumab potently reduces the growth rate of high-risk neuroblastoma xenografts. Pediatric Research 60 576-581. (doi:10.1203/01.pdr.0000242494.94000.52)

Shang X, Vasudevan SA, Yu Y, Ge N, Ludwig AD, Wesson CL, Wang K, Burlingame SM, Zhao Y-J, Rao PH et al. 2010 Dual-specificity phosphatase 26 is a novel p53 phosphatase and inhibits p53 tumor suppressor functions in human neuroblastoma. Oncogene 29 4938-4946. (doi:10.1038/onc.2010.244)

Shapiro GI 2006 Cyclin-dependent kinase pathways as targets for cancer treatment. Journal of Clinical Oncology 24 1770-1783. (doi:10.1200/JCO.2005.03.7689)

Shimada H, Ambros IM, Dehner LP, Hata J, Joshi VV \& Roald B 1999 Terminology and morphologic criteria of neuroblastic tumors: recommendations by the International Neuroblastoma Pathology Committee. Cancer 86 349-363. (doi:10.1002/(SICI)1097-0142(19990715) 86:2<349::AID-CNCR20>3.0.CO;2-Y)

Shiota M, Fujimoto J, Semba T, Satoh H, Yamamoto T \& Mori S 1994 Hyperphosphorylation of a novel $80 \mathrm{kDa}$ protein-tyrosine kinase similar to Ltk in a human $\mathrm{Ki}-1$ lymphoma cell line, AMS3. Oncogene 9 1567-1574.

Shu T, Tseng H-C, Sapir T, Stern P, Zhou Y, Sanada K, Fischer A, Coquelle FM, Reiner O \& Tsai L-H 2006 Doublecortin-like kinase controls neurogenesis by regulating mitotic spindles and $\mathrm{M}$ phase progression. Neuron 49 25-39. (doi:10.1016/j.neuron.2005.10.039)

Shusterman S \& Maris JM 2005 Prospects for therapeutic inhibition of neuroblastoma angiogenesis. Cancer Letters 228 171-179. (doi:10.1016/j.canlet.2005.01.049)

Sims TL, Williams RF, Ng CY, Rosati SF, Spence Y \& Davidoff AM 2008 Bevacizumab suppresses neuroblastoma progression in the setting of minimal disease. Surgery 144 269-275. (doi:10.1016/j.surg.2008.04.009)

Skrzydlewska E, Sulkowska M, Koda M \& Sulkowski S 2005 Proteolytic-antiproteolytic balance and its regulation in carcinogenesis. World Journal of Gastroenterology 11 1251-1266.

Soda M, Choi YL, Enomoto M, Takada S, Yamashita Y, Ishikawa S, Fujiwara S, Watanabe H, Kurashina K, Hatanaka H et al. 2007 Identification of the transforming EML4-ALK fusion gene in non-small-cell lung cancer. Nature 448 561-566. (doi:10.1038/nature05945)
Stenvang J, Silahtaroglu AN, Lindow M, Elmen J \& Kauppinen S 2008 The utility of LNA in microRNAbased cancer diagnostics and therapeutics. Seminars in Cancer Biology 18 89-102. (doi:10.1016/j.semcancer. 2008.01.004)

Swarbrick A, Woods SL, Shaw A, Balakrishnan A, Phua Y, Nguyen A, Chanthery Y, Lim L, Ashton LJ, Judson RL et al. 2010 miR-380-5p represses p53 to control cellular survival and is associated with poor outcome in MYCN-amplified neuroblastoma. Nature Medicine 16 1134-1140. (doi:10.1038/nm.2227)

Swartling FJ, Grimmer MR, Hackett CS, Northcott PA, Fan Q-W, Goldenberg DD, Lau J, Masic S, Nguyen K, Yakovenko S et al. 2010 Pleiotropic role for MYCN in medulloblastoma. Genes and Development 24 1059-1072. (doi:10.1101/gad.1907510)

Tanno B, Cesi V, Vitali R, Sesti F, Giuffrida ML, Mancini C, Calabretta B \& Raschellà G 2005 Silencing of endogenous IGFBP-5 by micro RNA interference affects proliferation, apoptosis and differentiation of neuroblastoma cells. Cell Death and Differentiation 12 213-223. (doi:10.1038/sj.cdd.4401546)

Tee Y-T, Chen G-D, Lin L-Y, Ko J-L \& Wang P-H 2006 NM23-H1: a metastasis-associated gene. Taiwanese Journal of Obstetrics \& Gynecology 45 107-113. (doi:10. 1016/S1028-4559(09)60206-0)

Tietze N, Pelisek J, Philipp A, Roedl W, Merdan T, Tarcha P, Ogris M \& Wagner E 2008 Induction of apoptosis in murine neuroblastoma by systemic delivery of transferrinshielded siRNA polyplexes for downregulation of Ran. Oligonucleotides 18 161-174. (doi:10.1089/oli.2008. 0112)

Tivnan A, Foley NH, Tracey L, Davidoff AM \& Stallings RL 2010 microRNA-184-mediated inhibition of tumour growth in an orthotopic murine model of neuroblastoma. Anticancer Research 30 4391-4395.

Tsarovina K, Schellenberger J, Schneider C \& Rohrer H 2008 Progenitor cell maintenance and neurogenesis in sympathetic ganglia involves Notch signaling. Molecular and Cellular Neurosciences 37 20-31. (doi:10.1016/j.mcn. 2007.08.010)

de Tudela MV-P, Delgado-Esteban M, Cuende J, Bolaños JP \& Almeida A 2010 Human neuroblastoma cells with MYCN amplification are selectively resistant to oxidative stress by transcriptionally up-regulating glutamate cysteine ligase. Journal of Neurochemistry 113 819-825. (doi:10.1111/j.1471-4159.2010.06648.x)

Verissimo CS, Molenaar JJ, Meerman J, Puigvert JC, Lamers F, Koster J, Danen EHJ, van de Water B, Versteeg R, Fitzsimons CP et al. 2010 Silencing of the microtubuleassociated proteins doublecortin-like and doublecortinlike kinase-long induces apoptosis in neuroblastoma cells. Endocrine-Related Cancer 17 399-414. (doi:10.1677/ ERC-09-0301)

Vreugdenhil E, Datson N, Engels B, de Jong J, van Koningsbruggen S, Schaaf M \& de Kloet ER 1999 Kainate-elicited seizures induce mRNA encoding a 
CaMK-related peptide: a putative modulator of kinase activity in rat hippocampus. Journal of Neurobiology 39 41-50. (doi:10.1002/(SICI)1097-4695(199904)39: $1<41:$ :AID-NEU4> 3.0.CO;2-X)

Vreugdenhil E, Engels B, Middelburg R, van Koningsbruggen S, Knol J, Veldhuisen B \& de Kloet ER 2001 Multiple transcripts generated by the $D C A M K L$ gene are expressed in the rat hippocampus. Brain Research. Molecular Brain Research 94 67-74. (doi:10.1016/S0169-328X(01)00213-3) Vreugdenhil E, Kolk SM, Boekhoorn K, Fitzsimons CP, Schaaf M, Schouten T, Sarabdjitsingh A, Sibug R \& Lucassen PJ 2007 Doublecortin-like, a microtubuleassociated protein expressed in radial glia, is crucial for neuronal precursor division and radial process stability. European Journal of Neuroscience 25 635-648. (doi:10.1111/j.1460-9568.2007.05318.x)

Wachowiak R, Thieltges S, Rawnaq T, Kaifi JT, Fiegel H, Metzger R, Quaas A, Mertens PR, Till H \& Izbicki JR 2010 Y-box-binding protein-1 is a potential novel tumour marker for neuroblastoma. Anticancer Research 30 1239-1242.

Wagner LM \& Danks MK 2009 New therapeutic targets for the treatment of high-risk neuroblastoma. Journal of Cellular Biochemistry 107 46-57. (doi:10.1002/jcb.22094)

Wang V \& Wu W 2009 microRNA-based therapeutics for cancer. BioDrugs 23 15-23. (doi:10.2165/00063030200923010-00002)

Wei JS, Song YK, Durinck S, Chen Q-R, Cheuk ATC, Tsang P, Zhang Q, Thiele CJ, Slack A, Shohet J et al. 2008 The MYCN oncogene is a direct target of miR-34a. Oncogene 27 5204-5213. (doi:10.1038/onc.2008.154)

Welch C, Chen Y \& Stallings RL 2007 microRNA-34a functions as a potential tumor suppressor by inducing apoptosis in neuroblastoma cells. Oncogene $\mathbf{2 6}$ 5017-5022. (doi:10.1038/sj.onc.1210293)

Wolf M, Korja M, Karhu R, Edgren H, Kilpinen S, Ojala K, Mousses S, Kallioniemi A \& Haapasalo H 2010 Array-based gene expression, $\mathrm{CGH}$ and tissue data defines a $12 q 24$ gain in neuroblastic tumors with prognostic implication. BMC Cancer 10 181. (doi:10. 1186/1471-2407-10-181)

Wolter J, Angelini P \& Irwin M 2010 p53 family: therapeutic targets in neuroblastoma. Future Oncology 6 429-444. (doi:10.2217/fon.09.176)
Wu W 2010 microRNA: potential targets for the development of novel drugs? Drugs in R\&D 10 1-8. (doi:10.2165/ 11537800-000000000-00000)

Wu W 2011 Modulation of microRNAs for potential cancer therapeutics. Methods in Molecular Biology 676 59-70. (doi:10.1007/978-1-60761-863-8_5)

Yeo E-J, Chun Y-S, Cho Y-S, Kim J, Lee J-C, Kim M-S \& Park J-W 2003 YC-1: a potential anticancer drug targeting hypoxia-inducible factor 1. Journal of the National Cancer Institute 95 516-525. (doi:10.1093/jnci/95.7.516)

Yoon KJ \& Danks MK 2009 Cell adhesion molecules as targets for therapy of neuroblastoma. Cancer Biology \& Therapy 8 306-311. (doi:10.4161/cbt.8.4.7446)

Zhang B, Pan X, Cobb GP \& Anderson TA $2007 a$ microRNAs as oncogenes and tumor suppressors. Developmental Biology 302 1-12. (doi:10.1016/j.ydbio. 2006.08.028)

Zhang L, Zhang X, Barrisford GW \& Olumi AF $2007 b$ Lexatumumab (TRAIL-receptor $2 \mathrm{mAb}$ ) induces expression of DR5 and promotes apoptosis in primary and metastatic renal cell carcinoma in a mouse orthotopic model. Cancer Letters 251 146-157. (doi:10.1016/j. canlet.2006.11.013)

Zheng X, Chou PM, Mirkin BL \& Rebbaa A 2004 Senescence-initiated reversal of drug resistance: specific role of cathepsin L. Cancer Research 64 1773-1780. (doi:10.1158/0008-5472.CAN-03-0820)

Zheng X, Chu F, Chou PM, Gallati C, Dier U, Mirkin BL, Mousa SA \& Rebbaa A 2009 Cathepsin L inhibition suppresses drug resistance in vitro and in vivo: a putative mechanism. American Journal of Physiology. Cell Physiology 296 C65-C74. (doi:10.1152/ajpcell.00082. 2008)

Zimmerman KA, Yancopoulos GD, Collum RG, Smith RK, Kohl NE, Denis KA, Nau MM, Witte ON, Toran-Allerand D \& Gee CE 1986 Differential expression of myc family genes during murine development. Nature 319 780-783. (doi:10.1038/319780a0)

Received in final form 27 September 2011 Accepted 3 October 2011 Made available online as an Accepted Preprint 4 October 2011 